\title{
Effects of slow-release urea and rumen-protected methionine and histidine on performance of dairy cows
}

\author{
F. Giallongo, ${ }^{*}$ A. N. Hristov, ${ }^{* 1}$ J. Oh, ${ }^{*}$ T. Frederick, ${ }^{*}$ H. Weeks, ${ }^{*}$ J. Werner,† H. Lapierre,‡ R. A. Patton, $\S$ \\ A. Gehman,\# and C. Parysll \\ *Department of Animal Science, and \\ †Animal Resource Program, The Pennsylvania State University, University Park 16802 \\ †Dairy and Swine Research and Development Centre, Agriculture and Agri-Food Canada, Sherbrooke, QC, Canada J1M 0C8 \\ $\S N i t t a n y$ Dairy Nutrition Inc., Mifflinburg, PA 17844 \\ \#Alltech Inc., Nicholasville, KY, 40356 \\ IIEvonik Industries AG, 63457 Hanau, Germany
}

\section{ABSTRACT}

This experiment was conducted with the objective to investigate the effects of slow-release urea and rumenprotected (RP) Met and His supplementation of a metabolizable protein (MP)-deficient diet (according to NRC, 2001) on lactation performance of dairy cows. Sixty lactating Holstein cows were used in a 10-wk randomized complete block-design trial. Cows were fed a covariate diet for $2 \mathrm{wk}$ and then assigned to one of the following treatments for an 8-wk experimental period: (1) MP-adequate diet [AMP; $107 \%$ of MP requirements, based on the National Research Council (NRC, 2001)]; (2) MP-deficient diet (DMP; $95 \%$ of MP requirements); (3) DMP supplemented with slow-release urea (DMPU); (4) DMPU supplemented with RPMet (DMPUM); and (5) DMPUM supplemented with RPHis (DMPUMH). Total-tract apparent digestibility of dry matter, organic matter, neutral detergent fiber, and crude protein, and urinary $\mathrm{N}$ and urea- $\mathrm{N}$ excretions were decreased by DMP, compared with AMP. Addition of slow-release urea to the DMP diet increased urinary urea-N excretion. Dry matter intake (DMI) and milk yield (on average $44.0 \pm 0.9 \mathrm{~kg} / \mathrm{d}$ ) were not affected by treatments, except DMPUMH increased DMI and numerically increased milk yield, compared with DMPUM. Milk true protein concentration and yield were increased and milk fat concentration tended to be decreased by DMPUMH, compared with DMPUM. Cows gained less body weight on the DMP diet, compared with AMP. Plasma concentrations of His and Lys were not affected by treatments, whereas supplementation of RPMet increased plasma Met concentration. Plasma concentration of 3-methylhistidine was or tended to be higher for DMP compared with AMP and DMPU, respectively. Addition of RPHis to the DMPUM diet

Received August 26, 2014.

Accepted January 10, 2015.

${ }^{1}$ Corresponding author: anh13@psu.edu tended to increase plasma glucose and creatinine. In conclusion, feeding a 5\% MP-deficient diet (according to NRC, 2001) did not decrease DMI and yields of milk and milk components, despite a reduction in nutrient digestibility. Supplementation of RPHis increased DMI and milk protein concentration and yield. These results are in line with our previous data and suggest that His may have a positive effect on voluntary feed intake and milk production and composition in high-yielding dairy cows fed MP-deficient diets.

Key words: metabolizable protein, slow-release urea, rumen-protected methionine, rumen-protected histidine, dairy cow

\section{INTRODUCTION}

The use of rumen-protected (RP) limiting AA for high-producing dairy cows is generating interest in the US dairy industry in recent years, particularly with regard to feeding diets with reduced dietary protein (Hristov and Giallongo, 2014). Research has consistently demonstrated that lowering protein concentration of the diet is the most effective strategy to improve the efficiency of dietary $\mathrm{N}$ utilization for milk protein synthesis and to decrease urinary total and urea $\mathrm{N}$ excretions and consequent ammonia emissions from dairy farms (Huhtanen and Hristov, 2009; Aguerre et al., 2010; Hristov et al., 2011). Urinary urea has been shown to be the main contributor to emissions of ammonia (Lee et al., 2012b) and nitrous oxide from dairy manure, thus leading to air and water pollution (US EPA, 2011). In addition, feeding lower protein rations can decrease feed costs and improve farm profitability (Schwab and Ordway, 2004).

In some experiments, the decreased dietary protein did not affect production performance (Colmenero and Broderick, 2006; Lee et al., 2012c), whereas in others, milk and milk protein yields decreased, primarily through reduced DMI (Broderick et al., 2009; Lee et al., 2012a). In some studies, reducing dietary protein 
concentration decreased total-tract fiber digestibility, primarily attributed to lower RDP supply and ruminal ammonia concentration (Russell et al., 1992; Allen, 2000). In such situations, a potential strategy is to supplement the diet with a ruminally available source of $\mathrm{N}$, such as NPN, to mitigate the adverse effects triggered by the decreased digestibility of dietary fiber (Sinclair et al., 2008).

Feeding low-protein diets to dairy cows can also cause production losses due to insufficient supply of specific AA, thus limiting milk production and milk protein synthesis (NRC, 2001; Doepel and Lapierre, 2010). Under these conditions, supplementation with RPMet and RPLys generally resulted in a slight increase in milk protein yield (MPY; Patton, 2010; Sinclair et al., 2014). On the other hand, supplementation of dairy cow diets with RPLys alone showed no effect on MPY (Robinson, 2010). Histidine has been identified as a limiting AA in dairy cows in both European studies with grass silage-based diets with variable $\mathrm{CP}$ concentration (Kim et al., 1999; Vanhatalo et al., 1999) and North American, corn silage-based diets deficient in MP (Lee et al., 2012a,c). Lee et al. (2012a) reported a trend for increased DMI with addition of RPHis to a MP-deficient diet and suggested that, similarly to monogastric species, His may exert a positive effect on feed intake in dairy cows.

For this trial, we hypothesized that slow-release urea supplementation of a MP-deficient diet would alleviate the previously observed negative effect on total-tract fiber digestibility. We also hypothesized that addition of RPMet and specifically RPHis to a MP-deficient diet may increase DMI, milk yield, and MPY. Thus, the objective of this study was to evaluate the effects of slow-release urea and RPMet and RPHis supplementation of a MP-deficient diet, according to NRC (2001), on DMI, milk production and composition, plasma and muscle AA and His-dipeptide concentrations, and plasma metabolites in dairy cows.

\section{MATERIALS AND METHODS}

The cows involved in this experiment were cared for in accordance with the guidelines of the Animal Care and Use Committee at The Pennsylvania State University. The committee approved the experiment and all procedures carried out in the study.

\section{Animals and Experimental Design}

The trial was a randomized complete block design and was conducted in 2 phases in the tie-stall barn of The Pennsylvania State University's Dairy Teaching and Research Center. Phase 1 (January to March
2013) involved 30 lactating Holstein cows (5 primiparous and 25 multiparous) with the following means $( \pm \mathrm{SD})$ : milk yield, $43.7( \pm 7.52) \mathrm{kg} / \mathrm{d}$; DIM, $61( \pm 20.4)$ $\mathrm{d}$; parity $2( \pm 1.1)$ lactations; and $\mathrm{BW}, 645( \pm 62.8)$ $\mathrm{kg}$ at the beginning of the study. Phase 2 (April to June 2013) involved another 30 cows (12 primiparous and 18 multiparous) with the following means $( \pm \mathrm{SD})$ : milk yield, $40.0( \pm 6.61) \mathrm{kg} / \mathrm{d} ;$ DIM, $114( \pm 38.5)$ d; parity $2( \pm 1.2)$ lactations; and $\mathrm{BW}, 633( \pm 77.8) \mathrm{kg}$ at the beginning of the study. The duration of each phase of the experiment was $10 \mathrm{wk}$, including a 2 -wk covariate period, 2 wk of adaptation to the diets, and 6 wk of data collection. During the covariate period, all cows were fed the main herd diet, which contained feed ingredients similar to the experimental diets (\% of DM): corn silage, 45.6; alfalfa haylage, 9.9; grass hay, 5.1; cottonseed hulls, 4.5; corn grain, ground, 10.4; candy by-product meal, 4.5; whole, heated soybeans, 6.7; canola meal, 5.8; molasses, 4.2; Optigen (Alltech Inc., Nicholasville, KY), 0.3; and mineral and vitamin premix, 3 . The covariate diet contained (\% of DM) CP, 15.0; NDF, 31.4; NFC, 43.9; and ether extract, 4.8. The experimental diets (Table 1) were formulated using the NRC (2001) recommendation to meet or exceed the nutrient requirements, except MP for the MP-deficient $\operatorname{diet}$ (DMP) and DMP diet supplemented with $0.4 \%$ (DM basis) of a slow-release urea source (DMPU), of a lactating Holstein cow with BW of $650 \mathrm{~kg}$, yielding $45 \mathrm{~kg}$ of milk per day with $3.80 \%$ milk fat and $3.20 \%$ true protein, at $27 \mathrm{~kg} / \mathrm{d}$ of DMI. The DMP diet was formulated to be about 5 to $10 \%$ deficient in MP and RDP (according to NRC, 2001). The DMP diet was supplemented with slow-release urea (DMPU diet) to meet the RDP requirements of the cows and alleviate the potential negative effect of RDP deficiency on rumen function. The composition of the diets was the same in both phases of the experiment. Following the covariate period, cows within each phase of the trial were grouped into 6 blocks of 5 cows per block based on DIM and milk yield. Primiparous cows formed one block in phase 1. Parity was not considered a blocking factor in phase 2 of the trial. Within block, cows were randomly assigned to 1 of the following 5 dietary treatments: (1) MP-adequate diet [AMP; providing 107\% of MP requirements according to the NRC (2001)]; (2) DMP (providing 95\% of MP requirements); (3) DMPU (supplemented with Optigen; providing $92 \%$ of MP requirements); (4) DMPU supplemented with 30 $\mathrm{g}$ of RPMet per cow per day [Mepron (RP DL-Met); Evonik Industries AG, Hanau, Germany; DMPUM; providing $96 \%$ of MP requirements]; and (5) DMPUM supplemented with $50 \mathrm{~g}$ of RPHis per cow per day (experimental RP L-His. $\mathrm{HCl}$ product; Balchem Corp., New Hampton, NY; DMPUMH; providing 95\% of 
MP requirements). Diets were fed as TMR twice daily (0700 and $1400 \mathrm{~h}$ ), in equal portions, to ensure about $10 \%$ daily refusals. The 3 TMR were prepared using a Kuhn Knight model 3142 Reel Auggie Mixer Wagon (Kuhn Knight Inc., Brodhead, WI). The RPAA supplements (RPMet and RPHis) were top-dressed and mixed with a small portion of the DMPU diet at time of the morning feeding. Cows consume most feed after new feed delivery and after milking (DeVries et al., 2003), and although we did not measure RPAA consumption, it is safe to assume that the supplemented RPAA were completely consumed. Cows had free access to drinking water and were milked twice daily at 0500 and $1700 \mathrm{~h}$.

Ruminal degradability of His from the RPHis product (the same product used by Lee et al., 2012a) was determined in situ as described by Lee et al. (2012a), except 2 cows were used for the rumen incubation and $5 \mathrm{~g}$ of RPHis per bag was incubated in the rumen of the cows for $1,3,6,12$, and $24 \mathrm{~h}$. The RPHis product and in situ bag residues were analyzed for His at the University of Missouri-Columbia's Agricultural Experiment Station Chemical Laboratory (Columbia, $\mathrm{MO})$. Based on these data (67\% rumen escape) and assumed $80 \%$ intestinal digestibility (see Lee et al., 2012a), bioavailability of His from the RPHis product was estimated at $54 \%$. Based on the manufacturer data and in situ analysis, supplemented RPMet and RPHis were estimated to provide 18.4 and $11.0 \mathrm{~g} /$ cow per day of digestible Met (dMet) and His (dHis), respectively (Table 2). The doses and balances of RPMet and RPHis were calculated assuming dMet and dHis requirements of $2.2 \%$ of MP (Schwab et al., 2005; Lee et al., 2012a). Balance of digestible Lys was estimated by assuming digestible Lys requirement of $6.6 \%$ of MP (Schwab et al., 2005). All cows received recombinant bST (Posilac, Elanco Co., Greenfield, IN; $500 \mathrm{mg}$ ) intramuscularly at 14-d intervals.

\section{Sampling and Measurements}

Unless indicated otherwise, all analyses described in this section were performed during both phase 1 and phase 2 of the study.

Feed intake and milk yield of individual cows were recorded daily during the entire experiment. The TMR and refusals from each diet were sampled twice weekly and composited (equal-weight basis) by week and treatment. Individual feed ingredients were collected weekly, stored at $-20^{\circ} \mathrm{C}$, and then composited per phase. All samples were dried in a forced-air oven at $55^{\circ} \mathrm{C}$ for 72 $\mathrm{h}$ for DM determination and then ground with a Wiley Mill (1-mm screen; A. H. Thomas Co., Philadelphia, PA). Dry matter content of the TMR and refusals samples was used to calculate DMI from the as-fed
Table 1. Ingredient and chemical composition of the basal diets fed in the trial

\begin{tabular}{|c|c|c|c|}
\hline \multirow[b]{2}{*}{ Item } & \multicolumn{3}{|c|}{ Diet, ${ }^{1}$ Phase 1 and 2} \\
\hline & AMP & DMP & DMPU \\
\hline \multicolumn{4}{|l|}{ Ingredient, $\%$ of DM } \\
\hline Corn silage $^{2}$ & 43.3 & 43.3 & 43.3 \\
\hline Grass hay ${ }^{3}$ & 8.0 & 8.0 & 8.0 \\
\hline Cottonseed, hulls & 3.8 & 3.8 & 3.8 \\
\hline Forage & 55.1 & 55.1 & 55.1 \\
\hline Corn grain, ground & 9.9 & 14.9 & 14.5 \\
\hline Candy by-product meal ${ }^{4}$ & 6.0 & 6.0 & 6.0 \\
\hline Soybean seeds, whole, heated ${ }^{5}$ & 7.9 & 7.9 & 7.9 \\
\hline Canola meal, mechanically extracted ${ }^{6}$ & 8.0 & 8.0 & 8.0 \\
\hline SoyPLUS ${ }^{7}$ & 7.0 & 2.0 & 2.0 \\
\hline Molasses ${ }^{8}$ & 3.4 & 3.4 & 3.4 \\
\hline Optigen $^{9}$ & - & - & 0.4 \\
\hline Mineral-vitamin premix ${ }^{10}$ & 2.7 & 2.7 & 2.7 \\
\hline \multicolumn{4}{|l|}{ Composition, $\%$ of DM } \\
\hline $\mathrm{CP}^{11,12}$ & 16.7 & 14.8 & 15.8 \\
\hline $\mathrm{RDP}^{13}$ & 9.2 & 8.6 & 9.7 \\
\hline RUP $^{13}$ & 7.5 & 6.2 & 6.1 \\
\hline $\mathrm{NDF}^{11}$ & 31.4 & 30.8 & 30.8 \\
\hline $\mathrm{ADF}^{11}$ & 18.9 & 18.7 & 18.7 \\
\hline Starch $^{11}$ & 25.7 & 29.1 & 28.8 \\
\hline $\mathrm{NE}_{\mathrm{L}},{ }^{13} \mathrm{Mcal} / \mathrm{kg}$ & 1.60 & 1.57 & 1.59 \\
\hline $\mathrm{NE}_{\mathrm{J}}$ balance. ${ }^{13} \mathrm{Mcal} / \mathrm{d}$ & 3.24 & 3.12 & 1.81 \\
\hline $\mathrm{NFC}^{13}$ & 43.0 & 45.7 & 44.7 \\
\hline $\mathrm{Ash}^{11}$ & 5.67 & 5.43 & 5.42 \\
\hline $\mathrm{Ca}^{11}$ & 0.65 & 0.63 & 0.63 \\
\hline $\mathrm{P}^{11}$ & 0.40 & 0.38 & 0.38 \\
\hline
\end{tabular}

${ }^{1} \mathrm{AMP}=\mathrm{MP}$-adequate diet; DMP $=$ MP-deficient diet; DMPU $=\mathrm{DMP}$ diet supplemented with Optigen (Alltech Inc., Nicholasville, KY). Two additional diets were fed in this study: DMPUM = DMPU diet supplemented with $30 \mathrm{~g}$ of rumen-protected Met (RPMet) per cow per day (Mepron; Evonik Industries AG, Hanau, Germany); and DMPUMH = DMPUM diet supplemented with $50 \mathrm{~g}$ of rumen-protected His (RPHis) per cow per day (Balchem Corp., New Hampton, NY).

${ }^{2}$ Corn silage was 45.1 and $41.3 \% \mathrm{DM}$ and contained (DM basis) 8.9 and 8.5\% CP, 39.1 and $41.7 \%$ starch, and 37.5 and $32.1 \%$ NDF (phase 1 and 2 , respectively).

${ }^{3}$ Grass hay was $86.2 \% \mathrm{DM}$ and (DM basis) $6.4 \% \mathrm{CP}$ and $73.5 \% \mathrm{NDF}$ (average of phase 1 and 2)

${ }^{4}$ Candy by-product meal (Graybill Processing, Elizabethtown, PA) contained (DM basis) 17\% CP and 27.8\% NDF (average of phase 1 and 2).

${ }^{5}$ Soybean seeds contained (DM basis) 40.0\% CP (average of phase 1 and 2).

${ }^{6}$ Canola meal contained (DM basis) $42.2 \% \mathrm{CP}$ (average of phase 1 and 2).

${ }^{7}$ SoyPLUS (West Central Cooperative, Ralston, IA) contained (DM basis) $46.9 \% \mathrm{CP}$ (average of phase 1 and 2).

${ }^{8}$ Molasses (Westway Feed Products, Tomball, TX) contained (DM basis) $3.9 \% \mathrm{CP}$ and $66 \%$ total sugar.

${ }^{9}$ Optigen is a slow-release urea.

${ }^{10}$ The premix (Cargill Animal Nutrition, Cargill Inc., Roaring Spring, PA) contained (\%, as-is basis) trace mineral mix, 0.86; $\mathrm{MgO}(56 \% \mathrm{Mg})$ 8.0; $\mathrm{NaCl}, 6.4$; vitamin ADE premix (Cargill Animal Nutrition, Cargil Inc.), 0.48; limestone, 37.2; selenium premix (Cargill Animal Nutrition, Cargill Inc.), 0.07; and dry corn distillers grains with solubles, 46.7. It also contained the following: Ca, $14.1 \% ; \mathrm{P}, 0.39 \% ; \mathrm{Mg}, 4.59 \% ; \mathrm{K}, 0.44 \%$; $\mathrm{S}, 0.39 \%$; Se, $6.91 \mathrm{mg} / \mathrm{kg}$; Cu, $362 \mathrm{mg} / \mathrm{kg}$; Zn, 1,085 mg/kg; Fe, $186 \mathrm{mg} /$ $\mathrm{kg}$; vitamin A, 276,717 IU/kg; vitamin D, 75,000 IU/kg; and vitamin E, $1,983 \mathrm{IU} / \mathrm{kg}$.

${ }^{11}$ Values calculated using the chemical analysis (Cumberland Valley Analytical Services Inc., Maugansville, MD) of individual feed ingredients of the diet.

${ }^{12}$ Crude protein content of the DMPUM and DMPUMH diets was 15.9 and $16.0 \%$, respectively.

${ }^{13}$ Estimated based on the NRC (2001). 
Table 2. Effects of slow-release urea and rumen-protected (RP) AA supplementation on feed intake, milk production and composition, and BW in dairy cows

\begin{tabular}{|c|c|c|c|c|c|c|c|c|c|c|}
\hline \multirow[b]{2}{*}{ Item } & \multicolumn{5}{|c|}{$\operatorname{Diet}^{1,2}$} & \multirow[b]{2}{*}{$\mathrm{SEM}^{3}$} & \multicolumn{4}{|c|}{ Contrast $^{4}$} \\
\hline & $\mathrm{AMP}$ & DMP & DMPU & DMPUM & DMPUMH & & MP & $\mathrm{U}$ & Met & His \\
\hline DMI, kg/d & 27.6 & 27.0 & 26.8 & 26.6 & 28.3 & 0.55 & 0.48 & 0.82 & 0.77 & 0.04 \\
\hline Milk yield, $\mathrm{kg} / \mathrm{d}$ & 43.8 & 43.7 & 43.3 & 42.8 & 45.3 & 1.17 & 0.96 & 0.82 & 0.72 & 0.11 \\
\hline Milk yield/DMI, $\mathrm{kg} / \mathrm{kg}$ & 1.62 & 1.63 & 1.63 & 1.64 & 1.61 & 0.041 & 0.88 & 0.93 & 0.92 & 0.65 \\
\hline Milk fat, $\%$ & 3.51 & 3.59 & 3.57 & 3.77 & 3.38 & 0.18 & 0.76 & 0.95 & 0.38 & 0.09 \\
\hline Milk true protein, $\%$ & 3.19 & 3.14 & 3.21 & 3.16 & 3.26 & 0.033 & 0.35 & 0.17 & 0.32 & 0.05 \\
\hline Milk lactose ${ }^{5} \%$ & 4.69 & 4.69 & 4.74 & 4.69 & 4.73 & 0.036 & 0.91 & 0.22 & 0.24 & 0.35 \\
\hline MUN, mg/dL & 14.5 & 12.5 & 13.7 & 13.7 & 13.1 & 0.60 & 0.02 & 0.16 & 0.92 & 0.39 \\
\hline Milk fat yield, $\mathrm{kg} / \mathrm{d}$ & 1.56 & 1.51 & 1.54 & 1.64 & 1.53 & 0.087 & 0.70 & 0.81 & 0.40 & 0.33 \\
\hline Milk protein yield, $\mathrm{kg} / \mathrm{d}$ & 1.39 & 1.38 & 1.39 & 1.39 & 1.48 & 0.035 & 0.77 & 0.76 & 0.89 & 0.05 \\
\hline Lactose, $\mathrm{kg} / \mathrm{d}$ & 2.07 & 2.08 & 2.07 & 2.06 & 2.16 & 0.059 & 0.88 & 0.84 & 0.90 & 0.18 \\
\hline $\mathrm{ECM}^{6}{ }^{6} \mathrm{~kg} / \mathrm{d}$ & 41.1 & 39.8 & 40.8 & 41.9 & 41.7 & 1.43 & 0.53 & 0.61 & 0.58 & 0.90 \\
\hline ECM/DMI, kg/kg & 1.47 & 1.48 & 1.53 & 1.57 & 1.46 & 0.043 & 0.92 & 0.43 & 0.46 & 0.07 \\
\hline $\mathrm{SCC}^{5}$ & 437 & 298 & 261 & 450 & 166 & 71.8 & 0.69 & 0.29 & 0.37 & 0.10 \\
\hline Milk $\mathrm{NE}_{\mathrm{J}}{ }^{7} \mathrm{Mcal} / \mathrm{d}$ & 30.6 & 29.6 & 30.4 & 31.3 & 31.0 & 1.07 & 0.53 & 0.61 & 0.57 & 0.88 \\
\hline $\mathrm{BW}, \mathrm{kg}$ & 652 & 644 & 650 & 657 & 658 & 4.6 & 0.19 & 0.35 & 0.31 & 0.92 \\
\hline BW change, ${ }^{8} \mathrm{~g} / \mathrm{d}$ & 289 & 16 & 220 & 203 & 330 & 82.2 & 0.03 & 0.09 & 0.88 & 0.29 \\
\hline BW change, kg & 19.7 & 1.09 & 15.1 & 13.5 & 22.4 & 5.593 & 0.03 & 0.09 & 0.85 & 0.28 \\
\hline
\end{tabular}

${ }^{1} \mathrm{AMP}=\mathrm{MP}$-adequate diet; DMP = MP-deficient diet; DMPU = DMP diet supplemented with Optigen (Alltech Inc., Nicholasville, KY); DMPUM = DMPU diet supplemented with RPMet (Mepron; Evonik Industries AG, Hanau, Germany); DMPUMH = DMPUM diet supplemented with RPHis (Balchem Corp., New Hampton, NY).

${ }^{2}$ Covariate-adjusted LSM for DMI, milk yield, and milk composition and yields.

${ }^{3}$ Largest SEM published in table. DMI and milk yield, $\mathrm{n}=405$; milk yield/DMI, $\mathrm{n}=402 ; \mathrm{BW}, \mathrm{n}=394 ; \mathrm{BW}$ change, $\mathrm{n}=57 ;$ milk composition data, $\mathrm{n}=53$ to 59 ( $\mathrm{n}$ represents number of observations used in the statistical analysis).

¿ $\quad{ }^{4} \mathrm{MP}=\mathrm{DMP}$ vs. AMP; U = DMPU vs. DMP; Met = DMPUM vs. DMPU; and His = DMPUMH vs. DMPUM.

${ }_{5}^{5}$ Statistical analysis was performed on log-transformed data. Outliers were removed based on an absolute studentized residual value $>3$ (PROC REG of SAS, SAS Institute Inc., ( Cary, NC).

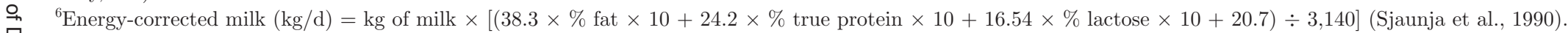

$\stackrel{{ }^{7}}{\triangleq} \mathrm{Milk} \mathrm{NE}_{\mathrm{L}}(\mathrm{Mcal} / \mathrm{d})=\mathrm{kg}$ of milk $\times(0.0929 \times \%$ fat $+0.0563 \times \%$ true protein $+0.0395 \times \%$ lactose $)(\mathrm{NRC}, 2001)$.

${ }^{8} \mathrm{BW}$ change, $\mathrm{g} / \mathrm{d}=$ (average $\mathrm{BW}$, final week of trial - average BW, second week of covariate period) $\div$ days on trial (around $70 \mathrm{~d}$ for most cows) 
TMR intake recorded daily. Composited feed-ingredient samples were sent to Cumberland Valley Analytical Services (Maugansville, MD) for wet chemistry analyses of $\mathrm{CP}, \mathrm{NDF}, \mathrm{ADF}$, starch, ash, $\mathrm{Ca}, \mathrm{P}$, and estimated $\mathrm{NFC}$ and $\mathrm{NE}_{\mathrm{L}}$ (analytical methods are available from CVAS, 2014). Samples of feed ingredients were also analyzed for AA (AOAC International, 1995; European Commission, 2009) by Evonik Industries AG. Performic acid oxidation was used for Met and Cys analysis, and Trp was analyzed after alkaline hydrolysis. Composite TMR samples were analyzed for indigestible NDF as described by Lee et al. (2012a). The chemical composition of the diets (i.e., CP, NDF, ADF, starch, ash, Ca, and $\mathrm{P}$ ) was calculated by using the analyzed chemical composition of the individual feed ingredients and their inclusion in the TMR (Table 1). The RDP, RUP, $\mathrm{NE}_{\mathrm{L}}$ and $\mathrm{NE}_{\mathrm{L}}$ balance, and $\mathrm{NFC}$ were estimated based on the NRC (2001) using actual DMI, milk yield, milk composition, and BW of the cows throughout the trial.

Eight spot fecal and urine samples were collected on 3 consecutive days $(1000,1600$, and $2200 \mathrm{~h}$ on d 1; 0400, 1300, and $1900 \mathrm{~h}$ on d 2; and 0100 and $0800 \mathrm{~h}$ on d 3) during wk 6 and 8 of the experimental period. Fecal samples were processed and analyzed for DM, $\mathrm{OM}, \mathrm{CP}, \mathrm{NDF}$, and $\mathrm{ADF}$ as described in Lee et al. (2012a). Composite fecal samples were also analyzed for starch using an enzymatic-colorimetric procedure (Bach Knudsen, 1997). Urine samples were processed and analyzed for allantoin, uric acid, creatinine, urea$\mathrm{N}$, and total $\mathrm{N}$ as reported by Lee et al. (2012a). Total-tract apparent digestibility of nutrients (i.e., DM, $\mathrm{OM}, \mathrm{NDF}, \mathrm{ADF}, \mathrm{CP}$, and starch) was estimated using indigestible $\mathrm{NDF}$ as an internal digestibility marker, and microbial $\mathrm{N}$ outflow from the rumen was estimated based on urinary excretion of purine derivatives (Lee et al., 2012a).

Blood samples were collected from the tail vein or artery into heparinized tubes at 6,10 , and $14 \mathrm{~h}$ after the morning feeding on $\mathrm{d} 3$ of $\mathrm{wk} 2$ of the covariate period and wk 6 and 8 of the experimental period. Blood samples were immediately centrifuged $(1,500 \times g$ for $15 \mathrm{~min}$ at $\left.4^{\circ} \mathrm{C}\right)$, and plasma was stored at $-20^{\circ} \mathrm{C}$ until analysis. Aliquots of the plasma samples were composited on an equal-volume basis per cow and week, samples from wh 6 and 8 were composited, and the composite samples were analyzed for urea-N (Stanbio Urea Nitrogen Kit 0580; Stanbio Laboratory Inc., Boerne, TX); insulin (Coat-A-Count; Siemens Healthcare Diagnostics Inc., Los Angeles, CA); and glucose, creatinine, and creatinine kinase (Idexx VetTest Chemistry; Idexx Laboratories Inc., Westbrook, ME). Plasma was also analyzed for concentrations of AA, 3-methylhistidine (3-MH), and the dipeptides carnosine and anserine at the University of Missouri-Columbia's Agricultural
Experiment Station Chemical Laboratory following the procedures of Deyl et al. (1986) and Fekkes (1996).

Muscle biopsies of longissimus dorsi were collected from all cows in phase 1 and from 15 randomly selected cows (3 cows per treatment) in phase 2 , at the end of the experimental period (wk 8). Of the cows selected for biopsy in phase 2, 10 were primiparous and 5 multiparous (not evenly distributed by parity among treatments). Biopsies were performed while animals were immobilized in a cattle chute. The surgical area (between the 12th and 13th transverse processes on the left side of the animal) was shaved and disinfected by alternating scrubs of $7.5 \%$ povidone iodine and $99 \%$ isopropyl alcohol. Muscle samples were obtained after local anesthesia $(8 \mathrm{~mL}$ of $2 \%$ lidocaine- $\mathrm{HCl}$, Phoenix Pharmaceuticals Inc., St. Joseph, MO) by performing a 1-cm incision through the skin and underlying soft tissue to expose the muscle with a sterile scalpel blade. An 8-mm sterile biopsy punch (Miltex Inc., York, PA) was used to remove a portion of the muscle, and then the skin was closed with a simple interrupted absorbable suture. Tissues (at least $0.5 \mathrm{~g}$ per cow) were immediately weighed, frozen in liquid $\mathrm{N}_{2}$, and stored at $-80^{\circ} \mathrm{C}$ until analysis. Concentrations of $\mathrm{AA}$ and dipeptides in muscle tissue were analyzed as described above for plasma AA. Before analysis, tissue samples were homogenized in ice-cold homogenization buffer as described by Korzick et al. (2013).

Milk samples were collected from 2 consecutive milkings (p.m. and a.m.) during wk 2 of the covariate period and wh 4, 6, and 8 of the experimental period. One aliquot of each sample was placed in tubes with a preservative (2-bromo-2-nitropropane-1,3-diol) and analyzed by Dairy One laboratory (Pennsylvania DHIA, University Park, PA) for fat, true protein, lactose, and MUN (AOAC, 1990; method no. 972.16) using a MilkoScan 4000 (Foss Electric A/S, Hillerød, Denmark). Another aliquot was placed in tubes without preservative and stored at $-20^{\circ} \mathrm{C}$ until analysis for milk FA composition as described by Hristov et al. (2010). Milk composition data of consecutive milking samples were weighted for the amount of milk per milking and averaged by sampling week and experimental phase, and the average values were used in the statistical analysis.

Cow BW was recorded daily during the entire experiment using AfiFarm 3.04E scale system (S.A.E. Afikim, Rehovot, Israel) when cows exited the milk parlor. For the statistical analysis, BW data collected during the data-collection period of the trial (i.e., wk 3 to 8 ) were used. Cow BW change was calculated as the difference between average BW during the second week (i.e., 7 measurements) of the covariate period and the last week (wk 8; i.e., 7 measurements) of the experimental period. 


\section{Statistical Analysis}

All data were analyzed using SAS software (SAS Institute Inc., 2002-2012). All responses were assessed for distributional properties such as normality, skewness, and type (discrete vs. continuous). For most variables measured, an assumption of normality was appropriate. For some variables, appropriate nonnormal distributions were assumed (Stroup, 2014). These variables were milk lactose concentration-gamma, SCC-Poisson, urinary uric acid excretion - lognormal, some milk FA data-gamma or $\beta$, and some plasma and muscle AA data- lognormal distribution. All responses were modeled using a generalized linear mixed model (GLMM) approach using the SAS procedure GLIMMIX (Stroup, 2012). Blocks were assumed random effects, whereas phase, treatment, and experimental week were assumed fixed. For repeated-measures data, an autoregressive lag 1 correlation structure was used. Comparisons of means were carried out using preplanned single-degreeof-freedom contrasts as follows: $\mathrm{MP}=$ the DMP versus AMP; $\mathrm{U}=\mathrm{DMPU}$ versus DMP; Met $=\mathrm{DMPUM}$ versus DMPU; and His = DMPUMH versus DMPUM. All data are presented as least squares means or covariateadjusted least squares means. Significant differences were declared at $P \leq 0.05$. Differences at $0.05<P \leq$ 0.10 were considered a trend toward significance.

\section{RESULTS}

The NDF and ADF concentrations were similar among diets; however, the DMP and DMPU diets had higher starch and NFC concentrations compared with the AMP diet, because of the higher corn grain and lower SoyPLUS (West Central Cooperative, Ralston, IA) inclusion (to create the different MP levels). All experimental diets supplied $\mathrm{NE}_{\mathrm{L}}$ in excess of cow requirements (NRC, 2001).

Dry matter intake (during the entire data-collection period of the trial, i.e., wk 3 through wk 8) was increased $(P=0.04)$ and milk yield was numerically greater $(P=0.11)$ for DMPUMH compared with DMPUM (Table 2). No other differences among treatments in DMI or milk yield and in feed efficiency, milk $\mathrm{NE}_{\mathrm{L}}$, milk fat, lactose, and ECM yields were observed. Milk fat concentration tended to be decreased $(P=0.09)$ for DMPUMH versus DMPUM. Milk true-protein concentration and yield were increased $(P=0.05)$ with DMPUMH compared with DMPUM. Concentration of MUN was decreased $(P=0.02)$ by DMP compared with AMP. Because of the trend for decreased milk fat concentration and higher DMI with RPHis supplementation, ECM feed efficiency tended to be decreased $(P$ $=0.07)$ by DMPUMH versus DMPUM. Somatic cell count tended to be lower $(P=0.10)$ with DMPUMH than DMPUM. Cows fed DMP had or tended to have lower BW gain than cows fed $\operatorname{AMP}(P=0.03)$ or DMPU $(P=0.09)$.

Table 3 reports predicted protein fractions and AA balance based on the NRC (2001) using the experimental data (DMI, milk yield, milk composition, and BW) of individual cows. As expected, the AMP diet met or exceeded the MP requirements of the cows, whereas the DMP and the 3 DMPU diets were deficient in MP (according to the NRC, 2001). The AMP and DMP diets were estimated to be deficient in RDP; the 3 DMPU diets were also about $2 \%$ deficient in RDP. The predicted RUP balance was positive for AMP and negative for DMP and the DMPU diets. The RPMet-supplemented diets (DMPUM and DMPUMH) met the requirements of dMet according to Schwab et al. (2005). The estimated (NRC, 2001) dMet supply for the AMP diet was about $19 \%$ below, whereas dMet supply for DMP and DMPU was on average about $25 \%$ below the suggested requirements (Schwab et al., 2005). Assuming dHis requirements of $2.2 \%$ of MP (Lee et al., 2012a), the AMP diet met dHis requirements, whereas DMP, DMPU, and DMPUM were estimated to be about 9,12 , and $8 \%$ deficient in dHis, respectively. Rumen-protected His supplementation of the DMPUMH diet provided adequate amounts of dHis compared with the assumed requirements $(+7 \%)$. The diets were about 5,14 , and on average $12 \%$ digestible-Lys deficient (AMP, DMP, and the 3 DMPU diets, respectively; based on Schwab et al., 2005).

Intakes of DM, OM, NDF, and ADF (during the fecal and urine collection periods) were not affected by treatments (Table 4). Crude protein intake tended to be lower $(P=0.08)$ for the DMP diet compared with AMP and was not affected by slow-release urea and RPAA supplementation. Because of lower starch concentration of the AMP diet (Table 1), starch intake was higher $(P=0.03)$ for the DMP and DMPU diets than AMP. Total-tract apparent digestibilities of DM, $\mathrm{OM}, \mathrm{NDF}$, and $\mathrm{CP}$ were decreased $(P<0.001$ to 0.05$)$ by the DMP diet compared with AMP. Crude-protein digestibility was higher $(P=0.02)$ and NDF digestibility was numerically lower $(P=0.11)$ for DMPU versus DMP. Digestibilities of $\mathrm{CP}$ and starch were or tended to be decreased ( $P=0.04$ and 0.07 , respectively) by DMPUM compared with DMPU. Digestibility of ADF tended to be decreased $(P=0.09)$ by DMPUMH versus DMPUM.

Concentrations of 15:0 and 17:0 FA in milk fat were increased ( $P=0.04$ and 0.03 , respectively) by DMPUM compared with DMPU, and tended $(P=0.10)$ or were $(P<0.01)$ decreased, respectively, with DMPUMH versus DMPUM (Table 5). Concentrations of 14:1 tended 
Table 3. Slow-release urea and rumen-protected (RP) AA supplementation of the diets and protein and AA balance ${ }^{1}$ during the trial

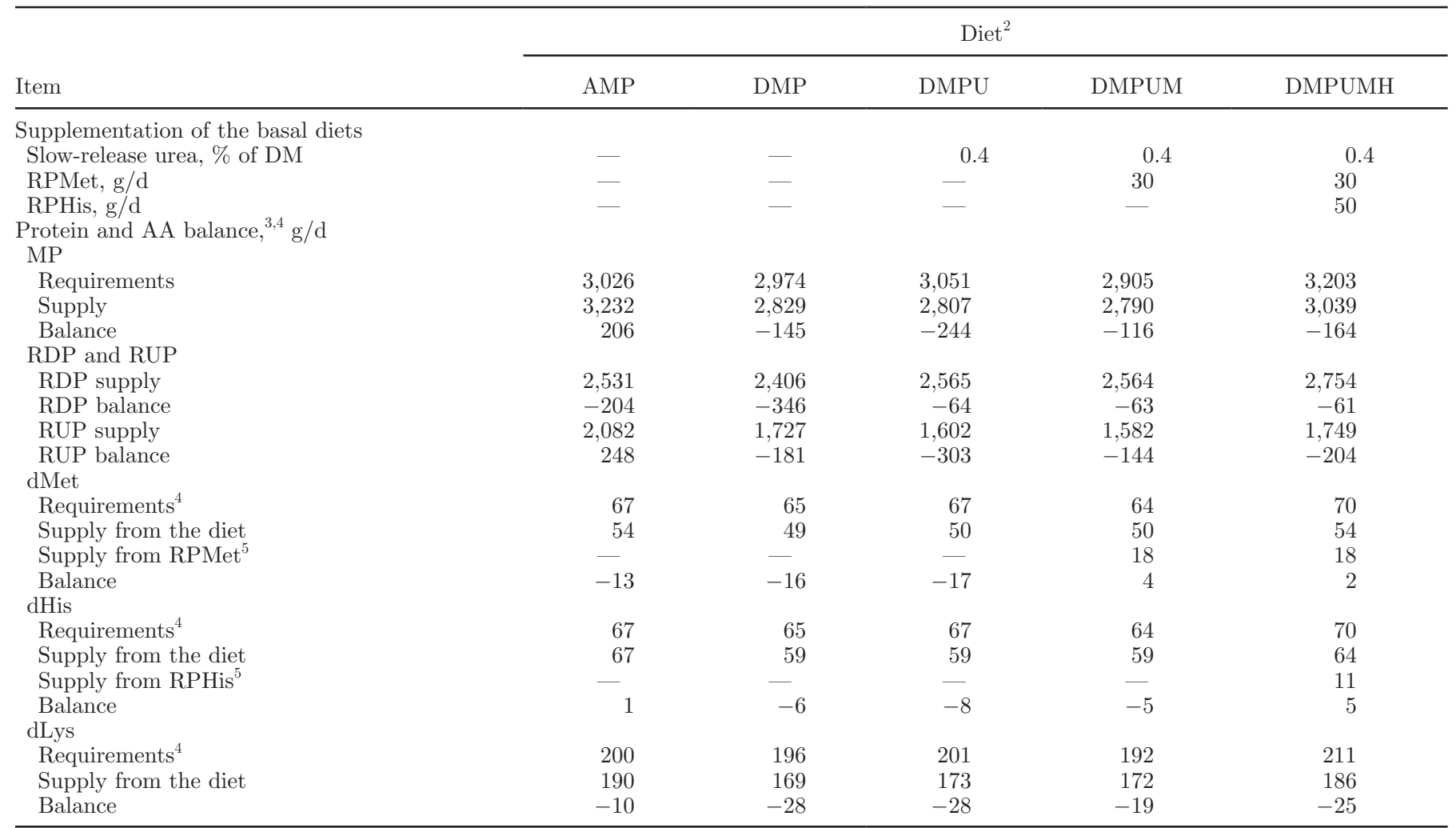

${ }^{1}$ All values were estimated using NRC (2001) recommendations based on actual averaged DMI, milk yield, milk composition, and BW of individual cows during 6 wk of data collection (i.e., wk 3 to 8 ).

${ }^{2} \mathrm{AMP}=\mathrm{MP}$-adequate diet; DMP = MP-deficient diet; DMPU = DMP diet supplemented with Optigen (Alltech Inc., Nicholasville, KY); DMPUM = DMPU diet supplemented with RPMet (Mepron; Evonik Industries AG, Hanau, Germany); DMPUMH = DMPUM diet supplemented with RPHis (Balchem Corp., New Hampton, NY).

${ }^{3}$ Because of rounding, balance may not exactly match requirements and supply; dMet, dHis, and dLys = digestible Met, His, and Lys, respectively.

${ }^{4}$ Requirements of dMet and dLys were calculated as 2.2 and $6.6 \%$, respectively, of MP requirements. Requirements of dHis were assumed as $2.2 \%$ of MP requirements (see Materials and Methods section).

${ }^{5}$ Digestible Met and His from RPMet, and RPHis, respectively, were estimated from Met and His content and bioavailability data provided by the manufacturer or determined in situ (in the case of RPHis): $85 \%$ Met and $72 \%$ bioavailability (RPMet), and $42 \%$ His and $54 \%$ bioavailability (67\% rumen escape and assumed $80 \%$ intestinal digestibility; RPHis).

to be decreased by DMP compared with $\operatorname{AMP}(P=$ $0.06)$ and DMPU $(P=0.09)$, whereas 18:3 tended to be decreased $(P=0.07)$ by DMPU versus DMP. Concentrations of other milk FA were not different between treatments. We observed phase $\times$ treatment interaction for 18:3 $(P=0.02)$, but no consistent differences were detected in 18:3 between phase 1 and 2 when the data were analyzed by phase.

Plasma Arg and Asp concentrations were higher $(P$ $=0.02$ and 0.04, respectively) for DMPUMH compared with DMPUM (Table 6). Concentrations of Arg and Trp were lower $(P=0.05$ and $<0.01$, respectively) for DMPU than DMP. Plasma His concentration was not affected by treatment. Concentration of Met was increased $(P=0.01)$ by DMPUM compared with DMPU. Concentration of Phe was increased by DMP $(P<0.01)$ and DMPUM $(P=0.05)$ compared with DMPU, and concentration of Ser tended to be increased $(P=0.06)$ by DMP compared with AMP. Plasma Ile concentration tended to be decreased $(P=0.07)$ and Val was decreased $(P=0.05)$ with DMP versus AMP. Plasma concentration of 3-MH was or tended to be increased by DMP compared with AMP $(P<0.01)$ and DMPU $(P$ $=0.06)$. Plasma Arg had a treatment $\times$ phase interaction $(P=0.05)$, but examination of the data by phase revealed similar trends for both experimental phases.

Concentrations of AA in longissimus dorsi tissue are presented in Table 7. Muscle concentrations of Ala, Ser, and Thr were decreased ( $P=0.01$ to 0.04$)$ for DMPUM versus DMPU. Muscle anserine level was increased $(P$ $=0.02)$ by DMPU compared with DMP. Concentration of muscle Glu was decreased $(P=0.02)$, and Asp 
Table 4. Effects of slow-release urea and rumen-protected (RP) AA supplementation on intake and total-tract apparent digestibility of nutrients in dairy cows

\begin{tabular}{|c|c|c|c|c|c|c|c|c|c|c|}
\hline \multirow[b]{2}{*}{ Item } & \multicolumn{5}{|c|}{$\operatorname{Diet}^{1}$} & \multirow[b]{2}{*}{$\mathrm{SEM}^{2}$} & \multicolumn{4}{|c|}{ Contrast $^{3}$} \\
\hline & $\mathrm{AMP}$ & DMP & DMPU & DMPUM & DMPUMH & & MP & $\mathrm{U}$ & Met & His \\
\hline DM & 27.6 & 28.0 & 26.4 & 26.3 & 28.6 & 1.26 & 0.84 & 0.36 & 0.94 & 0.18 \\
\hline $\mathrm{OM}$ & 24.8 & 25.3 & 23.8 & 23.7 & 25.7 & 1.13 & 0.73 & 0.32 & 0.93 & 0.18 \\
\hline $\mathrm{NDF}$ & 8.76 & 8.96 & 8.19 & 8.15 & 8.85 & 0.397 & 0.70 & 0.15 & 0.94 & 0.19 \\
\hline $\mathrm{ADF}$ & 5.59 & 5.82 & 5.43 & 5.40 & 5.87 & 0.261 & 0.52 & 0.26 & 0.94 & 0.18 \\
\hline \multicolumn{11}{|c|}{ Apparent digestibility, \% } \\
\hline DM & 73.4 & 72.0 & 71.9 & 71.0 & 70.5 & 0.41 & 0.02 & 0.90 & 0.13 & 0.35 \\
\hline OM & 73.0 & 71.7 & 71.4 & 70.6 & 70.1 & 0.44 & 0.04 & 0.65 & 0.20 & 0.36 \\
\hline $\mathrm{NDF}$ & 49.6 & 47.0 & 44.9 & 44.9 & 43.3 & 0.91 & 0.05 & 0.11 & 0.95 & 0.24 \\
\hline $\mathrm{ADF}$ & 43.1 & 42.8 & 41.2 & 41.2 & 38.9 & 0.93 & 0.74 & 0.27 & 0.98 & 0.09 \\
\hline $\mathrm{CP}$ & 72.9 & 68.4 & 71.3 & 68.8 & 69.6 & 0.85 & $<0.001$ & 0.02 & 0.04 & 0.49 \\
\hline Starch & 98.0 & 98.0 & 98.2 & 97.6 & 97.4 & 0.26 & 0.97 & 0.54 & 0.07 & 0.61 \\
\hline
\end{tabular}

${ }^{1} \mathrm{AMP}=\mathrm{MP}$-adequate diet; DMP = MP-deficient diet; DMPU = DMP diet supplemented with Optigen (Alltech Inc., Nicholasville, KY); DMPUM = DMPU diet supplemented with RPMet (Mepron; Evonik Industries AG, Hanau, Germany); DMPUMH = DMPUM diet supplemented with RPHis (Balchem Corp., New Hampton, NY).

${ }^{2}$ Largest SEM published in table; $\mathrm{n}=60$ ( $\mathrm{n}$ represents number of observations used in the statistical analysis).

${ }^{3} \mathrm{MP}=\mathrm{DMP}$ vs. AMP; U = DMPU vs. DMP; Met = DMPUM vs. DMPU; and His = DMPUMH vs. DMPUM.

${ }^{4}$ Intake data are for experimental wk 6 and 8.

and carnosine concentrations tended $(P=0.06$ to 0.08$)$ to be decreased, respectively, for DMPUMH compared with DMPUM. Concentrations of Gln and Gly were $(P=0.02)$ or tended $(P=0.06)$, respectively, to be increased with DMPUMH versus DMPUM. Muscle Gln, Gly, Lys, and Tyr concentrations tended to be decreased $(P=0.06$ to 0.08$)$ by DMPUM versus DMPU. Muscle 3-MH concentration was numerically higher $(P$ $=0.11)$ with DMP versus AMP and was decreased $(P$ $=0.04)$ by DMPUM compared with DMPU.

Concentration of blood glucose and creatinine tended to be higher ( $P=0.07$ to 0.09$)$ with DMPUMH versus DMPUM (Table 8). Plasma glucose and insulin levels were numerically increased $(P=0.12$ to 0.15$)$ with DMP compared with AMP. Blood urea-N was numerically decreased $(P=0.12)$ with DMP compared with AMP. Creatinine concentration was numerically higher $(P=0.13)$ for DMP versus AMP and for DMPUM compared with DMPU.

Nitrogen intake tended to be decreased $(P=0.08)$ by DMP compared with AMP during the fecal and urine collection periods (Table 9). Milk true-protein N secretion tended to be higher $(P=0.09)$ for DMPUMH than DMPUM. Estimated excretion of urinary $\mathrm{N}$ and urea-N (UUN) were decreased $(P<0.001)$ by 32 and $42 \%$, respectively, with DMP versus AMP. Compared with DMP, the DMPU diet increased $(P<0.001)$ by $55 \%$ UUN excretion and numerically increased $(P=$ 0.13 ) urinary $\mathrm{N}$ excretion. Excretion of UUN as a percentage of total urinary $\mathrm{N}$ was lowered $(P<0.001)$ by DMP compared with AMP and DMPU (47, 58, and
$64 \%$, respectively). This variable was also decreased $(P<0.01)$ by DMPUMH compared with DMPUM. Fecal $\mathrm{N}$ excretion tended to be increased $(P=0.08)$ by DMP versus AMP. Total $\mathrm{N}$ losses with feces and urine were not affected by treatments. As a proportion of $\mathrm{N}$ excretion, urinary $\mathrm{N}$ was decreased and fecal $\mathrm{N}$ was increased with DMP compared with AMP $(P<$ $0.001)$ and DMPU $(P=0.01)$. As a proportion of $\mathrm{N}$ intake, milk true-protein $\mathrm{N}$ secretion was increased $(P$ $=0.04)$ and urinary $\mathrm{N}$ excretion was decreased $(P<$ 0.01 ) by DMP compared with AMP. Fecal and total N excretion as a proportion of $\mathrm{N}$ intake were increased with DMP versus AMP $(P<0.001)$ and DMPU $(P<$ 0.01 and 0.03 , respectively) and were higher $(P=0.04$ and $<0.01$, respectively) for DMPUM than DMPU. Urine output, creatinine concentration and excretion, and urine output of purine derivatives and estimated microbial $\mathrm{N}$ outflow were not affected by treatments. There were treatment $\times$ phase interactions for urinary N excretion $(P=0.04)$, UUN as a proportion of total urinary $\mathrm{N}(P<0.001)$, and fecal and total $\mathrm{N}$ excretion as proportion of $\mathrm{N}$ intake $(P=0.03$ and 0.02 , respectively). However, analysis of the $\mathrm{N}$ excretion data by phase showed similar trends between phase 1 and 2 of the experiment. We observed an overall trend $(P \geq$ 0.03 ) for lower excretion of urinary $\mathrm{N}$ and UUN during phase 2, perhaps partly due to the slightly higher starch and lower NDF content of the corn silage fed in phase 2 versus phase 1 , which may have enhanced ammonia $\mathrm{N}$ utilization in the rumen in phase 2 of the study (Hristov et al., 2005). 
Table 5. Effects of slow-release urea and rumen-protected (RP) AA supplementation on milk FA composition ( $\mathrm{g} / 100 \mathrm{~g}$ of total FA) in dairy cows

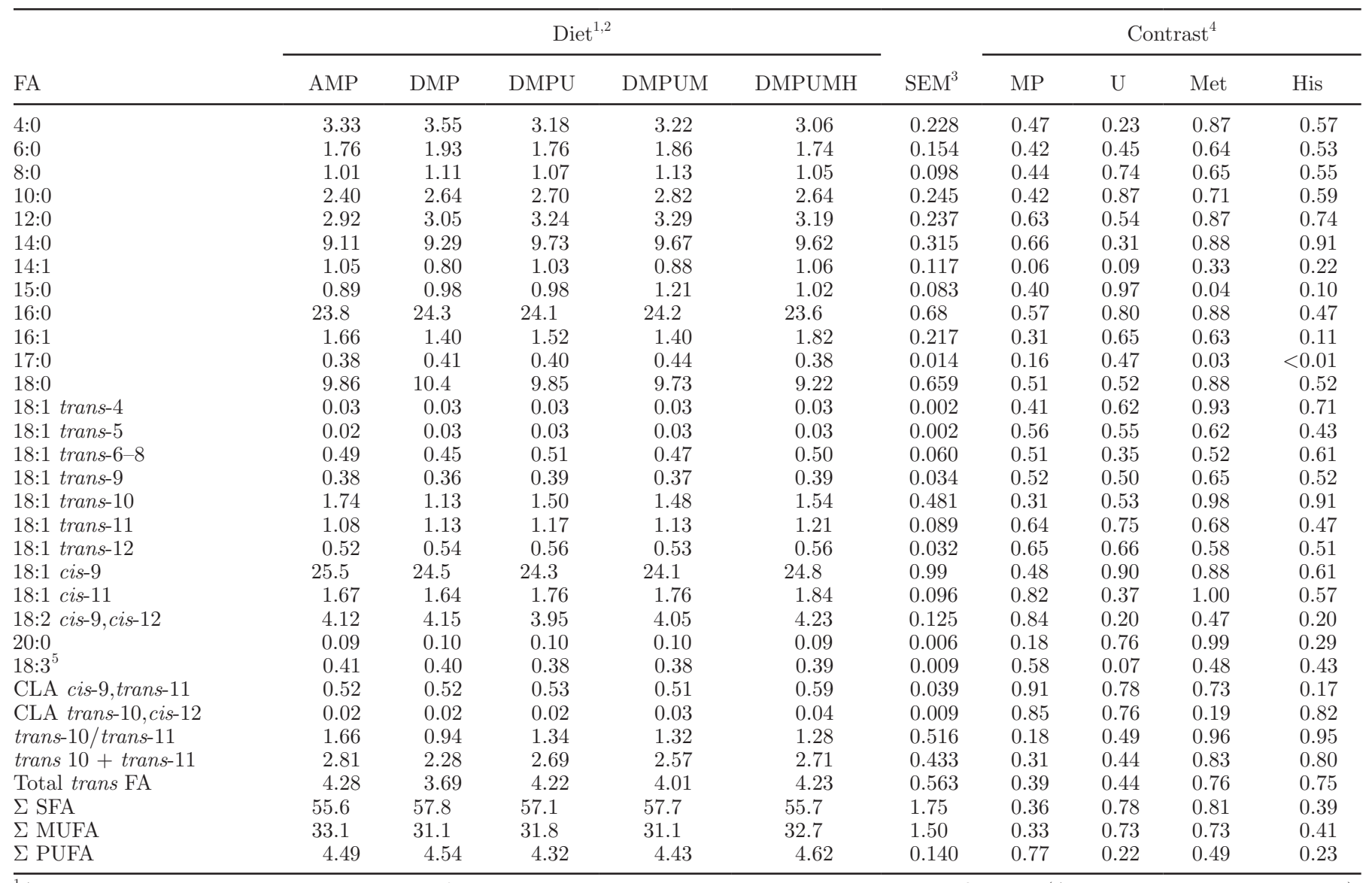

${ }^{1} \mathrm{AMP}=\mathrm{MP}$-adequate diet; DMP = MP-deficient diet; DMPU = DMP diet supplemented with Optigen (Alltech Inc., Nicholasville, KY); DMPUM = DMPU diet supplemented with RPMet (Mepron; Evonik Industries AG, Hanau, Germany); DMPUMH = DMPUM diet supplemented with RPHis (Balchem Corp., New Hampton, NY).

${ }^{2}$ Statistical analysis was performed on log-transformed data. Outliers were removed based on an absolute studentized residual value $>3$ (PROC REG of SAS, SAS Institute Inc., Cary, NC).

${ }^{3}$ Largest SEM published in table, $\mathrm{n}=21$ to 58 (n represents number of observations used in the statistical analysis).

${ }^{4} \mathrm{MP}=\mathrm{DMP}$ vs. AMP; U = DMPU vs. DMP; Met = DMPUM vs. DMPU; and His = DMPUMH vs. DMPUM.

${ }^{5}$ Experimental phase $\times$ treatment interaction $(P=0.02)$.

\section{DISCUSSION}

We did not observe a reduction in DMI with the DMP and DMPU diets in this experiment. Colmenero and Broderick (2006) and Kalscheur et al. (2006) also did not report a decline in DMI with even more dramatic reduction in dietary CP (from 19.4 to $13.5 \%$ and from 17.1 to $12.3 \%$, respectively). Our previous experiment (Lee et al., 2012a) on the other hand, showed a decrease in DMI of $1.5 \mathrm{~kg}$ when dietary $\mathrm{CP}$ was decreased from 15.7 to $13.5 \%$, representing a $13 \%$ deficiency of MP. Similar trends were observed by Haque et al. (2012), and a meta-analysis by Huhtanen and Hetta (2012) reported decreased feed intake and milk yield with reduced dietary protein intake. In agreement with Lee et al. (2012a,c), total-tract apparent digest- ibility of nutrients, in particular NDF, was decreased by the DMP diet in the current trial. The reduction in DMI in dairy cows fed RDP-deficient diets is commonly attributed to decreased digestibility of fiber in the rumen (Allen, 2000), due to the lower supply of ammonia to the fibrolytic bacteria (Russell et al., 1992). However, diets up to $10 \%$ deficient in RDP with a CP concentration of about $15 \%$ may be sufficient to prevent the decrease in DMI, even when fiber digestibility or microbial protein synthesis are negatively affected (Hristov and Giallongo, 2014). Consistent with these conclusions, in the current and other studies (Boucher et al., 2007; Lee et al., 2011a), DMI was not affected by dietary RDP levels below NRC (2001) requirements. Inaccurate estimation of feed $\mathrm{RDP}$ and unaccounted urea-N recycling have been suggested to contribute to 
Table 6. Effects of slow-release urea and rumen-protected (RP) AA supplementation on blood plasma AA and dipeptide concentrations ( $\mu M$ ) in dairy cows

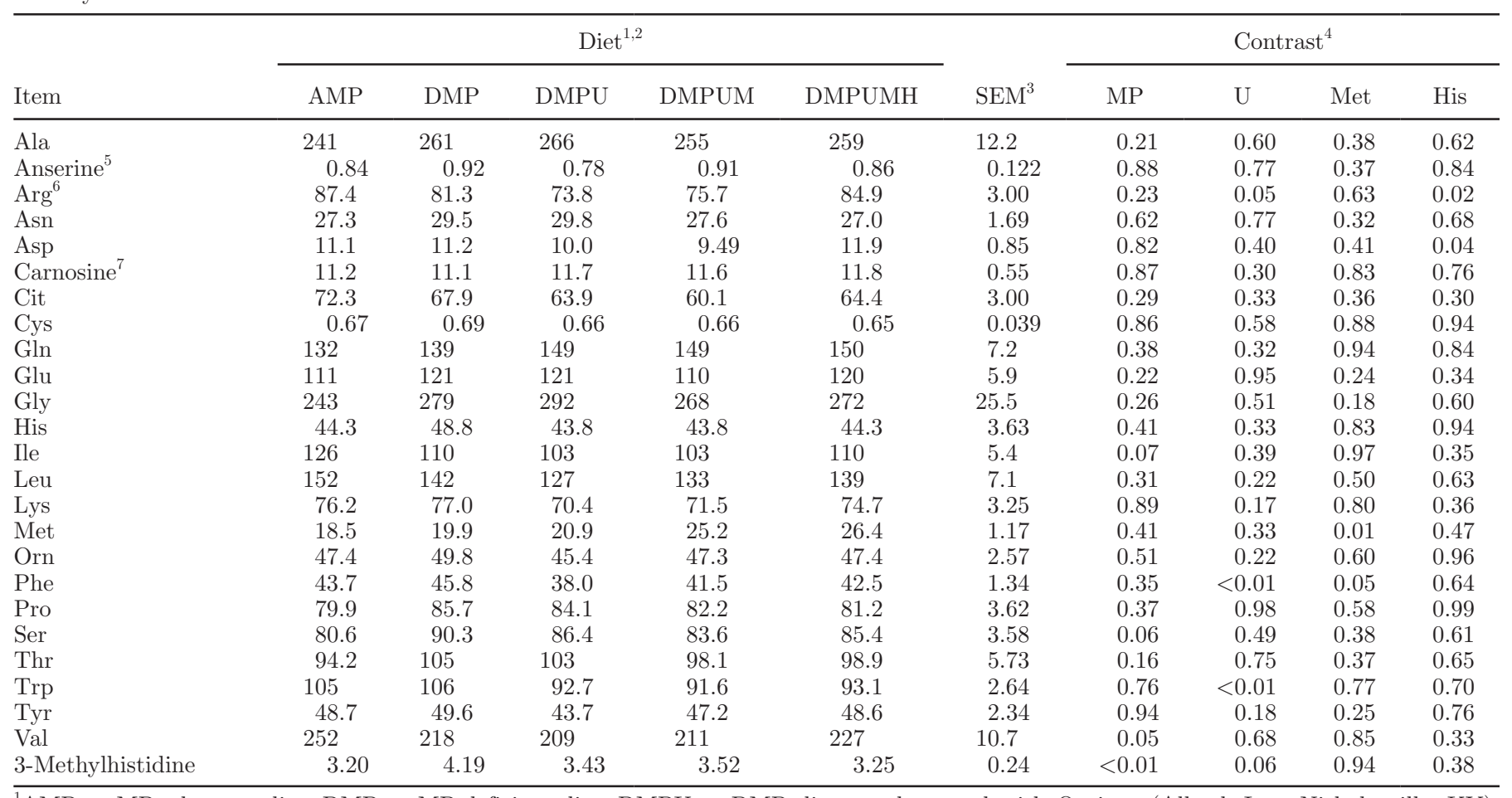

${ }^{1} \mathrm{AMP}=\mathrm{MP}$-adequate diet; DMP = MP-deficient diet; DMPU = DMP diet supplemented with Optigen (Alltech Inc., Nicholasville, KY); DMPUM = DMPU diet supplemented with RPMet (Mepron; Evonik Industries AG, Hanau, Germany); DMPUMH = DMPUM diet supplemented with RPHis (Balchem Corp., New Hampton, NY).

${ }^{2}$ Statistical analysis was performed on log-transformed data. Outliers were removed based on an absolute studentized residual value $>3$ (PROC REG of SAS, SAS Institute Inc., Cary, NC).

${ }^{3}$ Largest SEM published in table, $\mathrm{n}=55$ to 60 (n represents number of observations used in the statistical analysis).

${ }^{4} \mathrm{MP}=\mathrm{DMP}$ vs. AMP; U = DMPU vs. DMP; Met = DMPUM vs. DMPU; and His = DMPUMH vs. DMPUM.

${ }^{5}$ Dipeptide ( $\beta$-alanyl-1- $N$-methyl-L-His).

${ }^{6}$ Experimental phase $\times$ treatment interaction $(P=0.05$ for $\mathrm{Arg})$.

${ }^{7}$ Dipeptide ( $\beta$-alanyl-L-His).

the possible overestimation of RDP recommendations in NRC (2001; Huhtanen and Hristov, 2009).

Similar to our data, Galo et al. (2003) found no effect of slow-release urea supplementation on NDF digestibility in dairy cows. Addition of plain urea to dairy rations also had no effect on fiber digestibility (Cameron et al., 1991; Ahvenjärvi et al., 1999; Boucher et al., 2007). In contrast, Susmel et al. (1995) reported an increase in NDF digestibility by supplementing the control diet with urea, although the severe $\mathrm{N}$ deficiency in their study (CP was $9.4 \%$ of $\mathrm{DM}$ ) was likely the reason for the different response in comparison with the above-mentioned studies. In the current experiment, ammonia was most likely not a limiting factor for the growth and activity of fiber-degrading bacteria with the DMP diet, because fiber digestibility did not benefit from increased NPN supplied by slow-release urea. On the contrary, it is possible that RDP from true protein was limiting fiber degradability in the current study. It has been shown that free AA and peptides increase fiber digestion in vitro (Griswold et al., 1996; Carro and Miller, 1999) and in vivo in steers (McAllan, 1991) and the growth of rumen bacteria in sheep (Chikunya et al., 1996) and dairy cows (Broderick and Reynal, 2009). Total-tract apparent digestibility of CP was increased in the current experiment with the addition of slow-release urea to the DMP diet, and similar findings were reported for slow-release urea (Galo et al., 2003) and plain urea (Cameron et al., 1991; Susmel et al., 1995; Ahvenjärvi et al., 1999) supplementation. This effect can be attributed in part to decreased metabolic fecal $\mathrm{N}$ as a proportion of $\mathrm{N}$ intake (Wickersham et al., 2008).

In line with previous studies (Broderick et al., 2009; Patton, 2010; Chen et al., 2011), addition of RPMet had no effect on feed intake. Supplementation of the DMPUM diet with RPHis increased DMI $(+1.7 \mathrm{~kg} / \mathrm{d})$, which in turn led to a numerical increase in milk yield 
Table 7. Effects of slow-release urea and rumen-protected (RP) AA supplementation on muscle AA and dipeptide concentrations ( $\mu \mathrm{g} / \mathrm{g}$ ) in dairy cows

\begin{tabular}{|c|c|c|c|c|c|c|c|c|c|c|}
\hline Item & \multicolumn{5}{|c|}{$\operatorname{Diet}^{1,2}$} & $\mathrm{SEM}^{3}$ & \multicolumn{4}{|c|}{ Contrast $^{4}$} \\
\hline Ala & 62.4 & 66.6 & 75.1 & 59.5 & 60.2 & 6.19 & 0.79 & 0.19 & 0.04 & 0.74 \\
\hline Arg & 22.6 & 23.1 & 19.5 & 14.9 & 17.7 & 3.93 & 0.87 & 0.87 & 0.12 & 0.31 \\
\hline Asn & 8.35 & 10.2 & 10.5 & 8.22 & 8.20 & 1.026 & 0.16 & 0.96 & 0.15 & 0.92 \\
\hline Asp & 20.7 & 19.2 & 21.0 & 22.5 & 16.7 & 2.34 & 0.56 & 0.55 & 0.64 & 0.06 \\
\hline Cys & 2.15 & 2.34 & 2.55 & 2.59 & 2.61 & 0.18 & 0.39 & 0.25 & 1.00 & 0.85 \\
\hline Gln & 226 & 287 & 296 & 232 & 329 & 34.8 & 0.16 & 0.75 & 0.08 & 0.02 \\
\hline Glu & 152 & 179 & 188 & 176 & 126 & 15.3 & 0.31 & 0.53 & 0.56 & 0.02 \\
\hline Gly & 54.8 & 58.6 & 66.7 & 44.8 & 62.2 & 9.07 & 0.87 & 0.71 & 0.06 & 0.06 \\
\hline His & 8.42 & 9.45 & 8.89 & 7.79 & 7.32 & 1.120 & 0.57 & 0.92 & 0.47 & 0.31 \\
\hline Ile & 11.8 & 10.9 & 11.4 & 10.1 & 9.11 & 1.01 & 0.79 & 0.34 & 0.13 & 0.17 \\
\hline Leu & 16.7 & 14.9 & 15.9 & 13.8 & 12.5 & 1.41 & 0.58 & 0.32 & 0.14 & 0.22 \\
\hline Ser & 22.0 & 23.5 & 27.2 & 18.9 & 20.8 & 2.52 & 0.88 & 0.33 & 0.02 & 0.37 \\
\hline Thr & 14.2 & 16.2 & 16.2 & 12.5 & 13.0 & 1.14 & 0.25 & 0.97 & 0.01 & 0.41 \\
\hline Tyr & 10.1 & 9.65 & 10.2 & 8.68 & 8.27 & 0.754 & 0.75 & 0.32 & 0.06 & 0.60 \\
\hline Val & 22.6 & 19.2 & 20.5 & 19.2 & 18.4 & 1.55 & 0.15 & 0.33 & 0.35 & 0.48 \\
\hline 1-Methylhistidine & 3.22 & 3.22 & 3.42 & 2.87 & 2.95 & 0.336 & 1.00 & 0.71 & 0.22 & 0.94 \\
\hline 3-Methylhistidine & 0.89 & 1.21 & 1.13 & 0.80 & 0.86 & 0.14 & 0.11 & 0.97 & 0.04 & 0.92 \\
\hline
\end{tabular}

${ }^{1} \mathrm{AMP}=\mathrm{MP}$-adequate diet; DMP $=$ MP-deficient diet; DMPU = DMP diet supplemented with Optigen (Alltech Inc., Nicholasville, KY); DMPUM = DMPU diet supplemented with RPMet (Mepron; Evonik Industries AG, Hanau, Germany); DMPUMH = DMPUM diet supplemented with RPHis (Balchem Corp., New Hampton, NY).

${ }^{2}$ Statistical analysis was performed on log-transformed data. Outliers were removed based on an absolute studentized residual value $>3$ (PROC REG of SAS, SAS Institute Inc., Cary, NC).

${ }^{3}$ Largest SEM published in table, $\mathrm{n}=40$ to 42 ( $\mathrm{n}$ represents number of observations used in the statistical analysis).

${ }^{4} \mathrm{MP}=\mathrm{DMP}$ vs. AMP; $\mathrm{U}=$ DMPU vs. DMP; Met = DMPUM vs. DMPU; and His = DMPUMH vs. DMPUM.

${ }^{5}$ Dipeptide ( $\beta$-alanyl-1- $N$-methyl-L-His).

${ }^{6}$ Dipeptide ( $\beta$-alanyl-L-His).

$(+2.5 \mathrm{~kg} / \mathrm{d})$. These results confirm similar trends reported by Lee et al. (2012a) and data from postruminal infusion of His (Lapierre et al., 2014; Ouellet et al., 2014) and suggest that His may have a positive effect on voluntary feed intake in dairy cows. Data from a meta-analysis (R. A. Patton, A. N. Hristov, C. Parys, and H. Lapierre, unpublished data) also indicated no effect of Met and Lys on DMI, which is in line with previous meta-analyses (Patton, 2010; Robinson, 2010), but reported increased DMI and milk yield with His supplementation. The role of His in the control of feed intake has been demonstrated in earlier studies with

Table 8. Effects of slow-release urea and rumen-protected (RP) AA supplementation on blood plasma metabolites and insulin in dairy cows

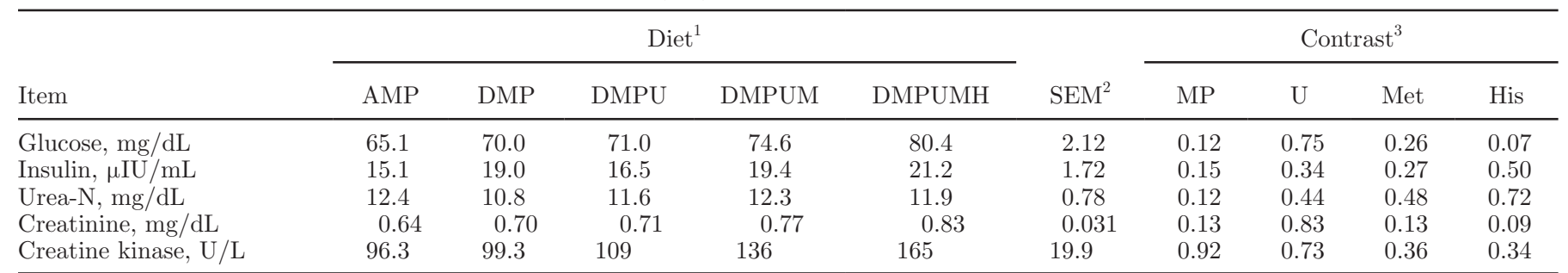

${ }^{1} \mathrm{AMP}=\mathrm{MP}$-adequate diet; DMP $=$ MP-deficient diet; DMPU = DMP diet supplemented with Optigen (Alltech Inc., Nicholasville, KY); DMPUM = DMPU diet supplemented with RPMet (Mepron; Evonik Industries AG, Hanau, Germany); DMPUMH = DMPUM diet supplemented with RPHis (Balchem Corp., New Hampton, NY).

${ }^{2}$ Largest SEM published in table; $\mathrm{n}=59$ to 60 ( $\mathrm{n}$ represents number of observations used in the statistical analysis).

${ }^{3} \mathrm{MP}=\mathrm{DMP}$ vs. AMP; U = DMPU vs. DMP; Met = DMPUM vs. DMPU; and His = DMPUMH vs. DMPUM. 
Table 9. Effects of slow-release urea and rumen-protected (RP) AA supplementation on milk N secretion, urinary and fecal N excretion, urine creatinine concentration, and urine purine-derivative $(\mathrm{PD})$ excretion in dairy $\operatorname{cows}^{1}$

\begin{tabular}{|c|c|c|c|c|c|c|c|c|c|c|}
\hline \multirow[b]{2}{*}{ Item } & \multicolumn{5}{|c|}{ Diet $^{2}$} & \multirow[b]{2}{*}{$\mathrm{SEM}^{3}$} & \multicolumn{4}{|c|}{ Contrast $^{4}$} \\
\hline & AMP & DMP & DMPU & DMPUM & DMPUMH & & MP & $\mathrm{U}$ & Met & His \\
\hline $\mathrm{N}$ intake, ${ }^{5} \mathrm{~g} / \mathrm{d}$ & 739 & 663 & 668 & 665 & 722 & 31.8 & 0.08 & 0.90 & 0.94 & 0.18 \\
\hline \multicolumn{11}{|l|}{$\mathrm{N}$ secretion and excretion, $\mathrm{g} / \mathrm{d}$} \\
\hline Milk TPN ${ }^{6}$ & 216 & 212 & 223 & 208 & 232 & 10.0 & 0.79 & 0.42 & 0.27 & 0.09 \\
\hline Urinary $\mathrm{N}^{7}$ & 171 & 116 & 134 & 141 & 152 & 8.80 & $<0.001$ & 0.13 & 0.54 & 0.37 \\
\hline Urinary urea-N, g/d & 98.2 & 56.6 & 87.5 & 97.0 & 91.0 & 6.20 & $<0.001$ & $<0.001$ & 0.22 & 0.43 \\
\hline As $\%$ of total urinary $\mathrm{N}^{7}$ & 57.6 & 47.4 & 63.9 & 67.3 & 59.2 & 2.21 & $<0.001$ & $<0.001$ & 0.23 & $<0.01$ \\
\hline Fecal N & 224 & 259 & 236 & 256 & 270 & 15.3 & 0.08 & 0.23 & 0.31 & 0.46 \\
\hline Total excreta $\mathrm{N}$ & 396 & 375 & 370 & 397 & 422 & 21.3 & 0.45 & 0.84 & 0.31 & 0.35 \\
\hline Total $\mathrm{N}$ in excreta and milk & 611 & 569 & 593 & 605 & 654 & 29.9 & 0.26 & 0.52 & 0.74 & 0.19 \\
\hline \multicolumn{11}{|l|}{ As proportion of $\mathrm{N}$ excretion, $\%$} \\
\hline Urine N & 42.9 & 31.0 & 36.3 & 35.6 & 36.1 & 1.35 & $<0.001$ & 0.01 & 0.73 & 0.79 \\
\hline Fecal N & 57.1 & 69.0 & 63.7 & 64.4 & 63.9 & 1.35 & $<0.001$ & 0.01 & 0.73 & 0.79 \\
\hline \multicolumn{11}{|l|}{ As proportion of $\mathrm{N}$ intake, $\%$} \\
\hline Milk TPN & 29.5 & 32.6 & 33.5 & 31.6 & 32.3 & 1.10 & 0.04 & 0.51 & 0.18 & 0.62 \\
\hline Urine N & 23.0 & 17.9 & 20.1 & 21.2 & 21.1 & 1.02 & $<0.01$ & 0.15 & 0.47 & 0.97 \\
\hline Fecal $\mathrm{N}^{7}$ & 30.1 & 39.1 & 35.2 & 38.2 & 37.2 & 1.02 & $<0.001$ & $<0.01$ & 0.04 & 0.48 \\
\hline Total excreta $\mathrm{N}^{7}$ & 52.4 & 58.6 & 55.3 & 59.3 & 58.3 & 1.11 & $<0.001$ & 0.03 & $<0.01$ & 0.49 \\
\hline Total N in excreta and milk & 82.6 & 86.7 & 88.8 & 91.0 & 90.6 & 2.25 & 0.22 & 0.53 & 0.51 & 0.92 \\
\hline Urine output, L/d & 15.3 & 15.0 & 14.8 & 14.0 & 13.5 & 0.92 & 0.85 & 0.89 & 0.50 & 0.73 \\
\hline Urinary creatinine, $\mathrm{mg} / \mathrm{dL}$ & 131 & 128 & 128 & 140 & 150 & 7.25 & 0.80 & 0.98 & 0.25 & 0.32 \\
\hline Urinary creatinine, $\mathrm{g} / \mathrm{d}$ & 19.1 & 18.5 & 18.7 & 19.1 & 19.3 & 0.61 & 0.42 & 0.82 & 0.60 & 0.77 \\
\hline \multicolumn{11}{|l|}{ Urinary PD excretion, $\mathrm{mmol} / \mathrm{d}$} \\
\hline Allantoin & 587 & 569 & 566 & 556 & 510 & 30.6 & 0.70 & 0.94 & 0.82 & 0.30 \\
\hline Uric acid 8 & 65.1 & 60.4 & 62.1 & 59.5 & 66.2 & 6.59 & 0.63 & 0.75 & 0.68 & 0.56 \\
\hline Total PD & 654 & 634 & 632 & 615 & 568 & 33.0 & 0.67 & 0.97 & 0.73 & 0.32 \\
\hline Microbial N flow, ${ }^{9} \mathrm{~g} / \mathrm{d}$ & 447 & 433 & 431 & 419 & 384 & 24.0 & 0.69 & 0.97 & 0.72 & 0.31 \\
\hline
\end{tabular}

${ }^{1}$ Data in this table (N intake, milk true protein, and urinary and fecal $\mathrm{N}$ ) are for experimental wk 6 and 8 only when urine and fecal samples were collected.

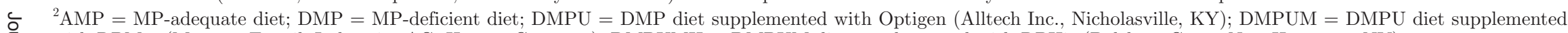

with RPMet (Mepron; Evonik Industries AG, Hanau, Germany); DMPUMH = DMPUM diet supplemented with RPHis (Balchem Corp., New Hampton, NY).

@ ${ }^{3}$ Largest SEM published in table; $\mathrm{n}=56$ to 60 ( $\mathrm{n}$ represents number of observations used in the statistical analysis).

을 ${ }^{4} \mathrm{MP}=\mathrm{DMP}$ vs. AMP; U = DMPU vs. DMP; Met = DMPUM vs. DMPU; and His = DMPUMH vs. DMPUM.

$\stackrel{{ }^{5}}{\equiv} \mathrm{N}$ intake data include $\mathrm{N}$ from supplemental RPAA.

( $\quad{ }^{6}$ Milk true-protein $\mathrm{N}$ (milk true protein $\div 6.38$ )

$\stackrel{\text { }}{\text { D. }} \quad{ }^{7}$ Experimental phase $\times$ treatment interaction $(P=0.04, P<0.001, P=0.03$, and $P=0.02$ for urinary $\mathrm{N}$, urinary urea-N as $\%$ of total urinary $\mathrm{N}$, fecal $\mathrm{N}$, and total excreta $\mathrm{N}$ as proportion of $\mathrm{N}$ intake \%, respectively).

${ }^{8}$ Statistical analysis was performed on log-transformed data. Outliers were removed based on an absolute studentized residual value $>3$ (PROC REG of SAS, SAS Institute Inc.,

을 Cary, NC).

${ }_{\infty}^{9}$ Estimated based on urinary PD excretion. 
several monogastric species. Stillings et al. (1969) and Makdani et al. (1971) observed a stimulatory effect of His on feed intake of weanling rats fed diets based on fish protein, and later, Kang-Lee and Harper (1977) found a linear increase in feed intake in young rats fed diets with increasing levels of His (from 0.1 to $0.25 \%$ by weight). Izquierdo et al. (1988) and Li et al. (2002) reported that feed intake and ADG of piglets rose linearly when dietary levels of His were increased from 0.19 to $0.31 \%$ and from 0.26 to $0.35 \%$ (as-fed basis), respectively. Infusion of His into the carotid artery also increased feed intake of cockerels fed a His-limiting diet (Tobin and Boorman, 1979). The anterior prepyriform cortex is suggested to be the brain's AA "chemosensor" (Beverly et al., 1990), and it has been shown to play a role in the initiation of the decrease in feed intake in rats fed AA-imbalanced or AA-deficient diets (Leung and Rogers, 1971; Firman and Kuenzel, 1988).

In line with other experiments (Colmenero and Broderick, 2006; Aguerre et al., 2010), feeding cows MP-deficient diets (according to the NRC, 2001; i.e., DMP, DMPU) did not decrease milk yield, milk protein concentration, and MPY in the current study, mostly because DMI was unaffected by the lowered supply of MP. Consistent with these results, and as reported by Lee et al. (2011a, 2012a,c; see discussions in Lee et al., 2012c), the NRC (2001) underpredicted MP-allowable milk yield of cows fed the DMP and DMPU diets by 3.2 and on average $3.7 \mathrm{~kg} / \mathrm{d}$, respectively. The NRC (2001) model overestimated milk yield of cows fed the AMP diet by $4.6 \mathrm{~kg} / \mathrm{d}$, most likely because of the oversupply of MP (206 g/d above requirements). However, other studies (Haque et al., 2012; Lee et al., 2012a) reported a negative effect of MP-deficient diets on milk yield and MPY, mainly as a result of decreased feed intake and consequent lowered supply of AA to the mammary gland. As discussed by Hristov and Giallongo (2014), a MP-deficiency of $-12 \%$ or greater (according to the NRC, 2001) is likely to trigger a negative response in DMI and consequently milk yield in dairy cows.

Similar to the findings of Lee et al. (2012c), RPMet supplementation had no effect on milk protein concentration, although some studies showed an increase in this production variable with addition of RPMet to the diet (Schwab et al., 2005; Patton, 2010; Chen et al., 2011). The level of MP and EAA supply (Broderick et al., 2009; Patton, 2010; Lee et al. 2012c) may be the reason for the different responses to RPMet observed among studies. In contrast to Lee et al. (2012a), addition of RPHis resulted in an increase in milk protein concentration, which in turn, together with the numerically increased milk yield, led to an increase in MPY. The milk protein response to RPHis in the current trial may be explained in part by increased DMI and consequent provision of EAA for milk protein synthesis (Lapierre et al., 2012b) and in part to the specific effect of increased dHis supply. Histidine has been shown to be a limiting AA in MP-deficient diets (Lee et al., 2012a), and infusion experiments have also reported a positive effect of His on milk protein concentration and MPY (Kim et al., 1999, 2001; Weekes et al., 2006). The trend for decreased milk fat concentration with His supplementation, which was not observed by Lee et al. (2012a) and others (Huhtanen et al., 2002), needs to be verified in further studies. However, some postruminal infusion studies have shown that the correction of His deficiency decreased milk fat percentage (Cant et al., 2001; Kim et al., 2001; Weekes et al., 2006).

Because of the low rumen degradability of the supplemented RPMet, we did not expect an increase in the concentration of linear odd-chain FA (15:0 and 17:0) in milk fat with the DMPUM diet. These FA, in fact, originate largely from rumen bacterial lipids and in small amounts from de novo synthesis in the mammary gland from propionate (Vlaeminck et al., 2006; French et al., 2012). In contrast, Rulquin et al. (2006) found no effect of RPMet on 15:0 and 17:0, but reported an increase in 15:0 (and no change in 17:0) with Met-derivatives supplementation. Although the rumen bypass rate of the Met source used in this study was higher compared with the Met derivatives used by Rulquin et al. (2006), it is possible that the observed changes in milk 15:0 and 17:0 were at least in part caused by its effect on the rumen microbial population. In an unrelated study from our laboratory (Lee et al., 2015), we also observed increased milk 15:0 and 17:0 with dietary 2-hydroxy-4-methylthio-butanoic acid (a Met analog known to have a relatively high rumen availability) supplementation.

In the current experiment, plasma His concentration was not decreased by the DMP and DMPU diets [which were, on average, $5.5 \%$ MP deficient (NRC, 2001)] compared with AMP. The lack of effect of MP deficiency on plasma His concentration in short-term, Latin-square design experiments (Lee et al., 2011b; Ouellet et al., 2013) has been attributed to the supply of His from endogenous pools (intramuscular carnosine and anserine, and blood hemoglobin; see discussion by Hristov and Giallongo, 2014). In contrast, Lee et al. (2012a,c) observed sharp decreases in plasma His with diets that were 12 to $15 \%$ deficient in MP. Similarly, Ouellet et al. (2013) did not report a decrease in plasma His with a diet that supplied $98 \%$ of MP requirements but observed a $57 \%$ decline with a $28 \%$ MP-deficient diet. On the other hand, Ouellet et al. (2014) found a linear decrease in plasma His and carnosine concentrations in dairy cows receiving a MP-adequate diet with decreasing levels of His infused postruminally. In the 
current study, the lack of effect on DMI together with the marginal deficiency of MP and dHis with the DMP (and DMPU) diet, likely contributed to prevent the decline in plasma His, and the consequent depletion of endogenous stocks of His (see following muscle AA discussion) with these diets. However, further research is needed to determine the changes in muscle carnosine and blood hemoglobin in long-term trials with cows fed diets more severely deficient in MP. The lack of effect of RPHis on plasma His in this study may be due in part to the shorter half-life of L-His compared, for example, with DL-Met (i.e., D-Met has a longer halflife than L-Met; Lapierre et al., 2012a). Another likely contributing factor is a greater removal of His by the mammary gland, as suggested by the increase in MPY with DMPUMH.

As previously reported with the same RPMet product (Preynat et al., 2009; Lee et al., 2012a), RPMet supplementation increased plasma Met in the current trial. In line with our previous study (Lee et al., 2012a), the DMP diet increased plasma concentration of the non-EAA, Ser, and decreased the branched-chain AA Ile and Val. Changes in plasma AA (i.e., Phe and Trp) concentrations with slow-release urea supplementation were not expected, although a lower concentration of the urea cycle intermediate, Arg (Garret and Grisham, 1999), with the addition of similar amounts of urea to a MP-deficient diet has been previously observed (Boucher et al., 2007).

The DMP diet increased plasma concentrations of $3-\mathrm{MH}$ and numerically increased intramuscular concentrations of $3-\mathrm{MH}$. These data, together with the observed lower BW gain of cows fed the DMP diet, indicate a decreased muscle protein synthesis or increased protein mobilization (Fetterer and Allen, 2000; van der Drift et al., 2012), probably to provide extra AA to support milk protein synthesis as a result of low dietary AA supply. Cows fed the MP-adequate diet and cows on the supplemented diets (i.e., slow-release urea and RPAA), on the other hand, were regaining BW lost in early lactation. These results may be related to increased muscular protein synthesis, because MPY was not affected by MP levels. In line with this hypothesis, the trend for increased plasma concentrations of creatinine, observed in cows fed the DMPUMH diet in the present experiment, have been associated with higher muscle mass (Perrone et al., 1992; Whittet et al., 2004).

Intramuscular concentrations of Gln have been positively associated with muscle protein synthesis (Millward et al., 1989; Wu et al., 2011). However, we did not observe lower concentration of this AA with the DMP diet. On the other hand, muscle Gln level was increased by RPHis supplementation, and this may be related to the numerically higher BW gain of the DMPUMH cows. The reduction in muscle Glu concentration with the DMPUMH diet also appears to be associated with the higher content of Gln in the muscle tissue of these cows (Durschlag and Smith, 1985). The lack of decrease in muscle carnosine concentrations with the DMP and DMPU diets is in agreement with the lack of treatment effect on plasma His, because it has been shown that muscle carnosine has a higher metabolic priority over plasma His (Clemens et al., 1984). In accordance with other studies conducted in monogastric species, muscle anserine concentration was not affected by the level of His in the diet (Amend et al., 1979; Clemens et al., 1984), although for unknown reasons, slow-release urea supplementation increased its concentration. A decreased muscle concentration of some AA (e.g., Ala, Ser, Thr) was observed following supplementation with RPMet, although, to the best of our knowledge, this effect has not been previously described in ruminant or nonruminant farm animals.

In line with previous experiments (Kröber et al., 2001; Misciatteilli et al., 2003), RPMet supplementation did not affect plasma glucose and insulin concentration. However, some studies reported an increase in plasma glucose (Berthiaume et al., 2001) or insulin (Blum et al., 1999; Kröber et al., 2000) in response to RPMet administration. In contrast to several His infusion studies (Vanhatalo et al., 1999; Kim et al., 2001; Weekes et al., 2006), addition of RPHis tended to increase plasma glucose concentration in the current trial. Proteins and their AA have gluconeogenic and insulinogenic effects (Ranawana and Kaur, 2013), and it is possible that the supplemental RPHis was responsible for the observed increases in plasma glucose concentration with the DMPUMH diet. The variable responses reported in the literature may arise from the specific effect or interactions among supplemented AA (Kuhara et al., 1991; Ranawana and Kaur, 2013), AA dosages (Liu et al., 2008), and nutrient composition of the diet (e.g., starch concentration; Rius et al., 2010). Unlike results from the current study, RPMet supplementation has been shown to reduce plasma creatinine (Kröber et al., 2001), or creatine kinase (Kröber et al., 2000).

As expected from experiments with low-CP diets (Colmenero and Broderick, 2006; Lee et al., 2011a, 2012a,c), the DMP diet decreased estimated excretion of urinary N and UUN. Reduction of urinary N excretion has been consistently shown to lower ammonia emissions from dairy manure (Hristov et al., 2011; Lee et al., 2012b). The increased excretion of UUN with the addition of slow-release urea can be mostly attributed to incomplete utilization of urea- $\mathrm{N}$ by rumen bacteria (Galo et al., 2003), and similar results have been reported with slow-release urea (Galo et al., 2003) and plain urea (Susmel et al., 1995; Ahvenjärvi et al., 
1999) supplementation. As noted previously (Lee et al., 2012a,c), RPAA had no effects on N excretion, although milk N secretion tended to increase with RPHis supplementation, as a result of the increase in MPY. Cows fed the MP-deficient diets had a greater milk $\mathrm{N}$ efficiency compared with those fed the AMP diet, indicating improved AA utilization for milk protein synthesis, due to the lower protein concentration of the diet and $\mathrm{N}$ intake (Huhtanen and Hristov, 2009).

\section{CONCLUSIONS}

In this experiment, DMI, yields of milk, and milk components were not affected by feeding dairy cows a diet that was $5 \%$ MP deficient based on the NRC (2001), in spite of the reduction in total-tract nutrient digestibility. However, likely because of low supply of AA, cows receiving the MP-deficient diet had elevated plasma 3-MH concentrations and were gaining less BW compared with the control and cows fed the slow-release urea and RPAA-supplemented diets. Supplementation of the MP-deficient diet with slow-release urea increased urinary urea-N excretion. Addition of RPMet increased plasma Met concentration but had no effect on milk production or composition. Supplementation with RPHis in addition to RPMet increased DMI and milk protein concentration and MPY. These results are in agreement with our previous data and suggest that His may have a positive effect on feed intake in dairy cows fed MP-deficient diets based on corn silage. As reported in previous experiments, feeding a MP-deficient diet markedly reduced urinary $\mathrm{N}$ excretion and, thus, is an effective strategy to decrease $\mathrm{N}$ losses from dairy operations.

\section{ACKNOWLEDGMENTS}

This study was partially supported by funds from a US Department of Agriculture (Washington, DC) Special Research Grants Program: Improved Dairy Management Practices, Evonik Industries AG (Hanau, Germany), and Alltech Inc. (Nicholasville, KY). The authors thank Evonik Industries AG for providing Mepron and for AA analyses of the feed samples, Alltech Inc. for providing Optigen, Balchem Corp. (New Hampton, NY) for providing RPHis, West Central Cooperative (Ralston, IA) for providing SoyPLUS for the trial, and the staff of the Department of Animal Science Dairy Center (The Pennsylvania State University, University Park) for their conscientious care of the experimental cows. The authors also thank B. Corl (Department of Dairy Science, Virginia Polytechnic Institute and State University) for the milk FA analysis and W. Price (Statistical Programs, College of Agricultural and Life
Sciences, University of Idaho) for assistance with statistical analysis of the data.

\section{REFERENCES}

Aguerre, M. J., M. A. Wattiaux, T. Hunt, and B. R. Larget. 2010. Effect of dietary crude protein on ammonia-N emission measured by herd nitrogen mass balance in a freestall dairy barn managed under farm-like conditions. Animal 4:1390-1400.

Ahvenjärvi, S., A. Vanhatalo, P. Huhtanen, and T. Varvikko. 1999 Effects of supplementation of a grass silage and barley diet with urea, rapeseed meal and heat-moisture-treated rapeseed cake on omasal digesta flow and milk production in lactating dairy cows. Acta Agric. Scand. A Anim. Sci. 49:179-189.

Allen, M. S. 2000. Effects of diet on short-term regulation of feed intake by lactating dairy cattle. J. Dairy Sci. 83:1598-1624.

Amend, J. F., D. H. Strumeyer, and H. Fisher. 1979. Effect of dietary histidine on tissue concentrations of histidine-containing dipeptides in adult cockerels. J. Nutr. 109:1779-1786.

AOAC (Association of Official Analytical Chemists). 1990. Official Methods of Analysis. 15th ed. AOAC, Arlington, VA.

AOAC International. 1995. Official Methods of Analysis. 16th ed. AOAC Int., Arlington, VA.

Bach Knudsen, K. E. 1997. Carbohydrate and lignin contents of plant materials used in animal feeding. Anim. Feed Sci. Technol. $67: 319-338$

Berthiaume, R., P. Dubreuil, M. Stevenson, B. W. McBride, and H. Lapierre. 2001. Intestinal disappearance and mesenteric and portal appearance of amino acids in dairy cows fed ruminally protected methionine. J. Dairy Sci. 84:194-203.

Beverly, J. L., D. W. Gietzen, and Q. R. Rogers. 1990. Effect of dietary limiting amino acid in prepyriform cortex on food intake. Am. J. Physiol. 259:R709-R715.

Blum, J. W., R. M. Bruckmaier, and F. Jans. 1999. Rumen-protected methionine fed to dairy cows: Bioavailability and effects on plasma amino acid pattern and plasma metabolite and insulin concentrations. J. Dairy Sci. 82:1991-1998.

Boucher, S. E., R. S. Ordway, N. L. Whitehouse, F. P. Lundy, P. J. Kononoff, and C. G. Schwab. 2007. Effect of incremental urea supplementation of a conventional corn silage-based diet on ruminal ammonia concentration and synthesis of microbial protein. J. Dairy Sci. 90:5619-5633.

Broderick, G. A., and S. M. Reynal. 2009. Effect of source of rumendegraded protein on production and ruminal metabolism in lactating dairy cows. J. Dairy Sci. 92:2822-2834.

Broderick, G. A., M. J. Stevenson, and R. A. Patton. 2009. Effect of dietary protein concentration and degradability on response to rumen-protected methionine in lactating dairy cows. J. Dairy Sci 92:2719-2728

Cameron, M. R., T. H. Klusmeyer, G. L. Lynch, J. H. Clark, and D. R. Nelson. 1991. Effects of urea and starch on rumen fermentation, nutrient passage to the duodenum, and performance of cows. J. Dairy Sci. 74:1321-1336.

Cant, J. P., D. R. Trout, F. Qiao, and B. W. McBride. 2001. Milk composition responses to unilateral arterial infusion of complete and histidine-lacking amino acid mixtures to the mammary glands of cows. J. Dairy Sci. 84:1192-1200.

Carro, M. D., and E. L. Miller. 1999. Effect of supplementing a fibre basal diet with different nitrogen forms on ruminal fermentation and microbial growth in an in vitro semi-continuous culture system (RUSITEC). Br. J. Nutr. 82:149-157.

Chen, Z. H., G. A. Broderick, N. D. Luchini, B. K. Sloan, and E. Devillard. 2011. Effect of feeding different sources of rumen-protected methionine on milk production and N-utilization in lactating dairy cows. J. Dairy Sci. 94:1978-1988.

Chikunya, S., C. J. Newbold, L. Rode, X. B. Chen, and R. J. Wallace. 1996. Influence of dietary rumen-degradable protein on bacterial growth in the rumen of sheep receiving different energy sources. Anim. Feed Sci. Technol. 63:333-340. 
Clemens, R. A., J. D. Kopple, and M. E. Swendseid. 1984. Metabolic effects of histidine-deficient diets fed to growing rats by gastric tube. J. Nutr. 114:2138-2146.

Colmenero, J. J. O., and G. A. Broderick. 2006. Effect of dietary crude protein concentration on milk production and nitrogen utilization in lactating dairy cows. J. Dairy Sci. 89:1704-1712.

CVAS (Cumberland Valley Analytical Services). 2014. ResourcesLab Procedures. Accessed Oct. 12, 2014. http://www.foragelab. com/Resources/Lab-Procedures/.

DeVries, T. J., M. A. G. von Keyserlingk, and K. A. Beauchemin. 2003. Short communication: Diurnal feeding pattern of lactating dairy cows. J. Dairy Sci. 86:4079-4082.

Deyl, Z., J. Hyanek, and M. Horakova. 1986. Profiling of amino acids in body fluids and tissues by means of liquid chromatography. J. Chromatogr. 379:177-250.

Doepel, L., and H. Lapierre. 2010. Changes in production and mammary metabolism of dairy cows in response to essential and nonessential amino acid infusions. J. Dairy Sci. 93:3264-3274.

Durschlag, R. P., and R. J. Smith. 1985. Regulation of glutamine production by skeletal muscle cells in culture. Am. J. Physiol. 248:C442-C448.

European Commission. 2009. 2009/150/EC Commission regulation laying down the methods of sampling and analysis for the official control of feed. Off. J. L54:1-130.

Fekkes, D. 1996. State-of-the-art of high-performance liquid chromatographic analysis of amino acids in physiological samples. J. Chromatogr. B, Biomed. Appl. 682:3-22.

Fetterer, R. H., and P. C. Allen. 2000. Eimeria acervulina infection elevates plasma and muscle 3-methylhistidine levels in chickens. J. Parasitol. 86:783-791.

Firman, J. D., and W. J. Kuenzel. 1988. Neuroanatomical regions of the chick brain involved in monitoring amino acid deficient diets. Brain Res. Bull. 21:637-642.

French, E. A., S. J. Bertics, and L. E. Armentano. 2012. Rumen and milk odd- and branched-chain fatty acid proportions are minimally influenced by ruminal volatile fatty acid infusions. J. Dairy Sci. 95:2015-2026.

Galo, E., S. M. Emanuele, C. J. Sniffen, J. H. White, and J. R. Knapp. 2003. Effects of a polymer-coated urea product on nitrogen metabolism in lactating Holstein dairy cattle. J. Dairy Sci. 86:21542162 .

Garret, R. H., and C. M. Grisham. 1999. Pages 852-898 in Biochemistry. . Harcourt Inc., Orlando, FL.

Griswold, K. E., W. H. Hoover, T. K. Miller, and W. V. Thayne. 1996. Effect of form of nitrogen on growth of ruminal microbes in continuous culture. J. Anim. Sci. 74:483-491.

Haque, M. N., H. Rulquin, A. Andrade, P. Faverdin, J. L. Peyraud, and S. Lemosquet. 2012. Milk protein synthesis in response to the provision of an "ideal" amino acid profile at 2 levels of metabolizable protein supply in dairy cows. J. Dairy Sci. 95:5876-5887.

Hristov, A. N., and F. Giallongo. 2014. Feeding protein to dairy cows - What should be our target? Pages 75-84 in Proc. Tri-State Dairy Nutr. Conf., Fort Wayne, IN. Ohio State Univ., Columbus.

Hristov, A. N., M. Hanigan, A. Cole, R. Todd, T. A. McAllister, P. M. Ndegwa, and A. Rotz. 2011. Review: Ammonia emissions from dairy farms and beef feedlots: A review. Can. J. Anim. Sci. 91:135.

Hristov, A. N., J. K. Ropp, K. L. Grandeen, S. Abedi, R. P. Etter, A. Melgar, and A. E. Foley. 2005. Effect of carbohydrate source on ammonia utilization in lactating dairy cows. J. Anim. Sci. $83: 408-421$

Hristov, A. N., G. Varga, T. Cassidy, M. Long, K. Heyler, S. K. R. Karnati, B. Corl, C. J. Hovde, and I. Yoon. 2010. Effect of Saccharomyces cerevisiae fermentation product on ruminal fermentation and nutrient utilization in dairy cows. J. Dairy Sci. 93:682-692.

Huhtanen, P., and M. Hetta. 2012. Comparison of feed intake and milk production responses in continuous and change-over design dairy cow experiments. Livest. Sci. 143:184-194.

Huhtanen, P., and A. N. Hristov. 2009. A meta-analysis of the effects of dietary protein concentration and degradability on milk protein yield and milk $\mathrm{N}$ efficiency in dairy cows. J. Dairy Sci. 92:3222-3232.

Huhtanen, P., A. Vanhatalo, and T. Varvikko. 2002. Effects of abomasal infusions of histidine, glucose, and leucine on milk production and plasma metabolites of dairy cows fed grass silage diets. J. Dairy Sci. 85:204-216.

Izquierdo, O. A., K. J. Wedekind, and D. H. Baker. 1988. Histidine requirement of the young pig. J. Anim. Sci. 66:2886-2892.

Kalscheur, K. F., R. L. Baldwin, B. P. Glenn, and R. A. Kohn. 2006 Milk production of dairy cows fed differing concentrations of rumen-degraded protein. J. Dairy Sci. 89:249-259.

Kang-Lee, Y. A., and A. E. Harper. 1977. Effect of histidine intake and hepatic histidase activity on the metabolism of histidine in vivo. J. Nutr. 107:1427-1443.

Kim, C.-H., J.-J. Choung, and D. G. Chamberlain. 1999. Determination of the first-limiting amino acid for milk production in dairy cows consuming a diet of grass silage and a cereal-based supplement containing feather meal. J. Sci. Food Agric. 79:1703-1708.

Kim, C.-H., J.-J. Choung, and D. G. Chamberlain. 2001. Estimates of the efficiency of transfer of L-histidine from blood to milk when it is the first-limiting amino acid for secretion of milk protein in the dairy cow. J. Sci. Food Agric. 81:1150-1155.

Korzick, D. H., D. R. Sharda, A. M. Pruznak, and C. H. Lang. 2013. Aging accentuates alcohol-induced decrease in protein synthesis in gastrocnemius. Am. J. Physiol. Regul. Integr. Comp. Physiol. 304:R887-R898

Kröber, T. F., M. Kreuzer, M. Senn, W. Langhans, and F. Sutter. 2000. Effects of rumen-protected methionine in a low protein ration on metabolic traits and performance of early lactating cows as opposed to rations with elevated crude protein content. J. Anim. Physiol. Anim. Nutr. (Berl.) 84:148-164.

Kröber, T. F., F. Sutter, M. Senn, W. Langhans, and M. Kreuzer. 2001. Effects of supplying leucine and methionine to early-lactating cows fed silage-concentrate based diets with a calculated deficiency in leucine and methionine. Anim. Res. 50:5-20.

Kuhara, T., S. Ikeda, A. Ohneda, and Y. Sasaki. 1991. Effects of intravenous infusion of 17 amino acids on the secretion of GH, glucagon, and insulin in sheep. Am. J. Physiol. Endocrinol. Metab. 260:E21-E26.

Lapierre, H., G. Holtrop, A. G. Calder, J. Renaud, and G. E. Lobley. 2012a. Is D-methionine bioavailable to the dairy cow? J. Dairy Sci. 95:353-362.

Lapierre, H., G. E. Lobley, L. Doepel, G. Raggio, H. Rulquin, and S. Lemosquet. 2012b. Triennial lactation symposium: Mammary metabolism of amino acids in dairy cows. J. Anim. Sci. 90:17081721.

Lapierre, H., D. R. Ouellet, and G. E. Lobley. 2014. Estimation of histidine requirement in lactating dairy cows. J. Dairy Sci. 97(Suppl. 1):757-758. (Abstr.).

Lee, C., A. N. Hristov, T. W. Cassidy, K. S. Heyler, H. Lapierre, G. A. Varga, M. J. de Veth, R. A. Patton, and C. Parys. 2012a. Rumenprotected lysine, methionine, and histidine increase milk protein yield in dairy cows fed a metabolizable protein-deficient diet. J. Dairy Sci. 95:6042-6056.

Lee, C., A. N. Hristov, C. J. Dell, G. W. Feyereisen, J. Kaye, and D. Beegle. 2012b. Effect of dietary protein concentration on ammonia and greenhouse gas emitting potential of dairy manure. J. Dairy Sci. 95:1930-1941.

Lee, C., A. N. Hristov, K. S. Heyler, T. W. Cassidy, H. Lapierre, G. A. Varga, and C. Parys. 2012c. Effects of metabolizable protein supply and amino acid supplementation on nitrogen utilization, milk production, and ammonia emissions from manure in dairy cows. J. Dairy Sci. 95:5253-5268.

Lee, C., A. N. Hristov, K. S. Heyler, T. W. Cassidy, M. Long, B. A. Corl, and S. K. R. Karnati. 2011a. Effects of dietary protein concentration and coconut oil supplementation on nitrogen utilization and production in dairy cows. J. Dairy Sci. 94:5544-5557.

Lee, C., A. N. Hristov, H. Lapierre, T. Cassidy, K. Heyler, G. A. Varga, and C. Parys. 2011b. Effect of dietary protein level and rumen-protected amino acid supplementation on dietary amino 
acid apparent digestibility and recovery in milk in lactating dairy cows. J. Dairy Sci. 94(Suppl. 1):689. (Abstr.)

Lee, C., J. Oh, A. N. Hristov, K. Harvatine, M. Vazquez-Anon, and G. I. Zanton. 2015. Effect of 2-hydroxy-4-methylthio-butanoic acid on ruminal fermentation, digestibility, and performance of lactating dairy cows. J. Dairy Sci. 98:1234-1247.

Leung, P. M., and Q. R. Rogers. 1971. Importance of prepyriform cortex in food-intake response of rats to amino acids. Am. J. Physiol. 221:929-935.

Li, D. F., J. H. Zhang, and L. M. Gong. 2002. Optimum ratio of histidine in the piglet ideal protein model and its effects on the body metabolism. II. Optimum ratio of histidine in 10-20 KG piglet ideal protein and its effects on blood parameters. Arch. Tierernahr. 56:199-212.

Liu, Z., P. B. Jeppesen, S. Gregersen, X. Chen, and K. Hermansen. 2008. Dose- and glucose-dependent effects of amino acids on insulin secretion from isolated mouse islets and clonal INS-1E betacells. Rev. Diabet. Stud. 5:232-244.

Makdani, D. D., J. T. Huber, and W. G. Bergen. 1971. Effect of histidine and methionine supplementation on the nutritional quality of commercially prepared fish protein concentrated in rat diets. J. Nutr. 101:367-375.

McAllan, A. B. 1991. Carbohydrate and nitrogen metabolism in the forestomach of steers given untreated or ammonia treated barley straw diets supplemented with urea or urea plus fishmeal. Anim. Feed Sci. Technol. 33:195-208.

Millward, D. J., M. M. Jepson, and A. Omer. 1989. Muscle glutamine concentration and protein turnover in vivo in malnutrition and in endotoxemia. Metabolism 38:6-13.

Misciatteilli, L., V. F. Kristensen, M. Vestergaard, M. R. Weisbjerg, K. Sejrsen, and T. Hvelplund. 2003. Milk production, nutrient utilization, and endocrine responses to increased postruminal lysine and methionine supply in dairy cows. J. Dairy Sci. 86:275-286.

NRC. 2001. Nutrient Requirements of Dairy Cattle. 7th rev. ed. Natl. Acad. Sci., Washington, DC.

Ouellet, D. R., G. E. Lobley, and H. Lapierre. 2014. Histidine requirement of dairy cows determined by the indicator amino acid oxidation (AAO) technique. J. Dairy Sci. 97(Suppl. 1):757. (Abstr.).

Ouellet, D. R., D. Valkeners, and H. Lapierre. 2013. Effects of metabolizable protein supply on $\mathrm{N}$ efficiency; Plasma amino acid concentrations in dairy cows. Pages 453-454 in Energy and Protein Metabolism and Nutrition in Sustainable Animal Production. EAAP publication No. 134. J. W. Oltjen, E. Kebreab, and H. Lapierre, ed. Wageningen Acad. Publ., Wageningen, the Netherlands.

Patton, R. A. 2010. Effect of rumen-protected methionine on feed intake, milk production, true milk protein concentration, and true milk protein yield, and the factors that influence these effects: A meta-analysis. J. Dairy Sci. 93:2105-2118.

Perrone, R. D., N. E. Madias, and A. S. Levey. 1992. Serum creatinine as an index of renal function: New insights into old concepts. Clin. Chem. 38:1933-1953.

Preynat, A., H. Lapierre, M. C. Thivierge, M. F. Palin, J. J. Matte, A. Desrochers, and C. L. Girard. 2009. Influence of methionine supply on the response of lactational performance of dairy cows to supplementary folic acid and vitamin B12. J. Dairy Sci. 92:1685-1695.

Ranawana, V., and B. Kaur. 2013. Role of proteins in insulin secretion and glycemic control. Adv. Food Nutr. Res. 70:1-47.

Rius, A. G., J. A. D. R. N. Appuhamy, J. Cyriac, D. Kirovski, O. Becvar, J. Escobar, M. L. McGilliard, B. J. Bequette, R. M. Akers, and M. D. Hanigan. 2010. Regulation of protein synthesis in mammary glands of lactating dairy cows by starch and amino acids. J. Dairy Sci. 93:3114-3127.

Robinson, P. H. 2010. Impacts of manipulating ration metabolizable lysine and methionine levels on the performance of lactating dairy cows: A systematic review of the literature. Livest. Sci. 127:115126.

Rulquin, H., B. Graulet, L. Delaby, and J. C. Robert. 2006. Effect of different forms of methionine on lactational performance of dairy cows. J. Dairy Sci. 89:4387-4394.

Russell, J. B., J. D. O'Connor, D. G. Fox, P. J. Van Soest, and C. J. Sniffen. 1992. A net carbohydrate and protein system for evaluat- ing cattle diets: I. Ruminal fermentation. J. Anim. Sci. 70:35513561.

SAS Institute Inc. 2002-2012. SAS/STAT User's Guide. Release 9.4. SAS Inst. Inc., Cary, NC.

Schwab, C. G., P. Huhtanen, C. W. Hunt, and T. Hvelplund. 2005. Nitrogen requirements of cattle. Pages $13-70$ in Nitrogen and Phosphorus Nutrition of Cattle and Environment. E. Pfeffer and A. N. Hristov, ed. CAB Int., Wallingford, UK.

Schwab, C. G., and R. S. Ordway. 2004. Balancing diets for amino acids: Implications of production efficiency and feed costs. Pages 1-16 in Proc. Penn State Dairy Cattle Nutr. Workshop, Grantville, PA. The Pennsylvania State University, University Park.

Sinclair, K. D., P. C. Garnsworthy, G. E. Mann, and L. A. Sinclair. 2014. Reducing dietary protein in dairy cow diets: Implications for nitrogen utilization, milk production, welfare and fertility. Animal $8: 262-274$

Sinclair, L. A., J. A. Huntington, and D. Wilde. 2008. Partial replacement of soyabean meal and rapeseed meal with a slow release urea source (Optigen II) and its effect on microbial growth and metabolism in vitro. Paper 224 in Proc. Br. Soc. Anim. Sci. Annu. Conf., Scarborough, UK. Br. Soc. Anim. Sci., Midlothian, UK.

Sjaunja, L. O., L. Baevre, L. Junkkarinen, J. Pedersen, and J. Setälä. 1990. A Nordic proposal for an energy corrected milk (ECM) formula. Proc. 27th Session Int. Comm. Breeding Product. Milk Anim., Paris, France. Wageningen Acad. Publ., Wageningen, the Netherlands.

Stillings, B. R., O. A. Hammerle, and D. G. Snyder. 1969. Sequence of limiting amino acids in fish protein concentrate produced by isopropyl alcohol extraction of red hake (Urophycis chuss). J. Nutr. 97:70-78.

Stroup, W. W. 2012. Generalized Linear Mixed Models: Modern Concepts, Methods and Applications. Page 555. Chapman Hall/CRC, London, UK.

Stroup, W. W. 2014. Rethinking the analysis of non-normal data in plant and soil science. Agron. J. 106:1-17.

Susmel, P., M. Spanghero, B. Stefanon, and C. R. Mills. 1995. Nitrogen balance and partitioning of some nitrogen catabolites in milk and urine of lactating cows. Livest. Prod. Sci. 44:207-219.

Tobin, G., and K. N. Boorman. 1979. Carotid or jugular amino acid infusions and food intake in the cockerel. Br. J. Nutr. 41:157-162.

US EPA (Environmental Protection Agency). 2011. Reactive Nitrogen in the United States: An Analysis of Inputs, Flows, Consequences, and Management Options. A Report of the EPA Science Advisory Board (EPA-SAB-11-013). EPA, Washington, DC.

van der Drift, S. G. A., M. Houweling, J. T. Schonewille, A. G. M. Tielens, and R. Jorritsma. 2012. Protein and fat mobilization and associations with serum $\beta$-hydroxybutyrate concentrations in dairy cows. J. Dairy Sci. 95:4911-4920.

Vanhatalo, A., P. Huhtanen, V. Toivonen, and T. Varvikko. 1999. Response of dairy cows fed grass silage diets to abomasal infusions of histidine alone or in combinations with methionine and lysine. J. Dairy Sci. 82:2674-2685.

Vlaeminck, B., V. Fievez, A. R. J. Cabrita, A. J. M. Fonseca, and R. J. Dewhurst. 2006. Factors affecting odd- and branched-chain fatty acids in milk: A review. Anim. Feed Sci. Technol. 131:389-417.

Weekes, T. L., P. H. Luimes, and J. P. Cant. 2006. Responses to amino acid imbalances and deficiencies in lactating dairy cows. J. Dairy Sci. 89:2177-2187.

Whittet, K. M., T. J. Klopfenstein, G. E. Erickson, T. W. Loy, and R. A. McDonald. 2004. Effect of age, pregnancy, and diet on urinary creatinine excretion in heifers and cows. Nebr. Beef Cattle Rep. MP 80A:100-102.

Wickersham, T. A., E. C. Titgemeyer, R. C. Cochran, E. E. Wickersham, and D. P. Gnad. 2008. Effect of rumen-degradable intake protein supplementation on urea kinetics and microbial use of recycled urea in steers consuming low-quality forage. J. Anim. Sci. 86:3079-3088.

Wu, G., F. W. Bazer, G. A. Johnson, D. A. Knabe, R. C. Burghardt, T. E. Spencer, X. L. Li, and J. J. Wang. 2011. Triennial growth symposium: Important roles for L-glutamine in swine nutrition and production. J. Anim. Sci. 89:2017-2030. 